\title{
Global warming potential and greenhouse gas intensity in rice agriculture driven by high yields and nitrogen use efficiency
}

\author{
Xiaoxu Zhang ${ }^{1}$, Xin $\mathrm{Xu}^{1}$, Yinglie Liu ${ }^{1}$, Jinyang Wang ${ }^{1,2}$, and Zhengqin Xiong ${ }^{1}$ \\ ${ }^{1}$ Jiangsu Key Laboratory of Low Carbon Agriculture and GHGs Mitigation, College of Resources and Environmental \\ Sciences, Nanjing Agricultural University, Nanjing 210095, China \\ ${ }^{2}$ State Key Laboratory of Soil and Sustainable Agriculture, Institute of Soil Science, Chinese Academy of Sciences, \\ Nanjing 210008, China
}

Correspondence to: Zhengqin Xiong (zqxiong@njau.edu.cn)

Received: 15 September 2015 - Published in Biogeosciences Discuss.: 26 November 2015

Revised: 18 April 2016 - Accepted: 28 April 2016 - Published: 10 May 2016

\begin{abstract}
Our understanding of how global warming potential (GWP) and greenhouse gas intensity (GHGI) is affected by management practices aimed at food security with respect to rice agriculture remains limited. In the present study, a field experiment was conducted in China to evaluate the effects of integrated soil-crop system management (ISSM) on GWP and GHGI after accounting for carbon dioxide $\left(\mathrm{CO}_{2}\right)$ equivalent emissions from all sources, including methane $\left(\mathrm{CH}_{4}\right)$ and nitrous oxide $\left(\mathrm{N}_{2} \mathrm{O}\right)$ emissions, agrochemical inputs and farm operations and sinks (i.e., soil organic carbon sequestration). The ISSM mainly consisted of different nitrogen $(\mathrm{N})$ fertilization rates and split, manure, $\mathrm{Zn}$ and $\mathrm{Na}_{2} \mathrm{SiO}_{3}$ fertilization and planting density for the improvement of rice yield and agronomic nitrogen use efficiency (NUE). Four ISSM scenarios consisting of different chemical $\mathrm{N}$ rates relative to the local farmers' practice (FP) rate were carried out, namely, ISSM-N1 (25\% reduction), ISSM-N2 (10\% reduction), ISSM-N3 (FP rate) and ISSM-N4 (25\% increase). The results showed that compared with the FP, the four ISSM scenarios significantly increased the rice yields by $10,16,28$ and $41 \%$ and the agronomic NUE by $75,67,35$ and $40 \%$, respectively. In addition, compared with the FP, the ISSM-N1 and ISSM-N2 scenarios significantly reduced the GHGI by 14 and $18 \%$, respectively, despite similar GWPs. The ISSM-N3 and ISSM-N4 scenarios remarkably increased the GWP and GHGI by an average of 69 and $39 \%$, respectively. In conclusion, the ISSM strategies are promising for both food security and environmental protection, and the ISSM scenario of ISSM-N2 is the optimal strategy to realize high yields and
\end{abstract}

high NUE together with low environmental impacts for this agricultural rice field.

\section{Introduction}

Rapid population growth and economic development place a growing pressure on increasing food production (Barrett, 2010). An increase in global crop production of $100 \%$ would be necessary to sustain the projected demand for human food and livestock feed in 2050 (Tilman et al., 2011). Rice is the staple food for nearly $50 \%$ of the world's people, mainly in Asia (Frolking et al., 2002). According to FAOSTAT (2010), approximately 600 million people in the Asia-Pacific region are suffering from hunger and malnutrition. With the region's population projected to increase by another billion by the mid-century, new approaches to increase food production are needed (Chen et al., 2014). With a limited agricultural land area, the intensive agricultural regions of China are facing serious environmental problems due to large inputs of chemical fertilizer and low nitrogen use efficiency (NUE) (Ju et al., 2009; Makino, 2011). Thus, integrated soil-crop system management (ISSM), which redesigns the whole production system based on the local environment and draws on appropriate fertilizer compounds and application ratios, crop densities and advanced water management regimes, has been advocated and developed to simultaneously increase crop productivity and NUE with low carbon dioxide $\left(\mathrm{CO}_{2}\right)$ equivalent emissions per unit product in China (Chen et al., 2014). The key points of the ISSM are to integrate soil and nutrient man- 
agement with high-yielding cultivation systems, to integrate the utilization of various nutrient sources and match nutrient supply to crop requirements, and to take all soil quality improvement measures into consideration (Zhang et al., 2011).

Carbon dioxide, methane $\left(\mathrm{CH}_{4}\right)$ and nitrous oxide $\left(\mathrm{N}_{2} \mathrm{O}\right)$ are the most important greenhouse gases (GHGs) that contribute to global warming (IPCC, 2013). The concept of global warming potential (GWP) has been applied to agricultural lands by taking into account of the radiative properties of all GHG emissions associated with agricultural production and soil organic carbon (SOC) sequestration, expressed as $\mathrm{CO}_{2}$ eq. $\mathrm{ha}^{-1} \mathrm{yr}^{-1}$ (Robertson and Grace, 2004; Mosier et al., 2006). Although agriculture releases significant amounts of $\mathrm{CH}_{4}$ and $\mathrm{N}_{2} \mathrm{O}$ into the atmosphere, the net emission of $\mathrm{CO}_{2}$ equivalents from farming activities can be partly offset by changing agricultural management to increase the soil organic matter content and/or decrease the emissions of $\mathrm{CH}_{4}$ and $\mathrm{N}_{2} \mathrm{O}$ (Mosier et al., 2006; Smith et al., 2008). If global agricultural techniques are improved, the mitigation potential of agriculture (excluding fossil fuel offsets from biomass) is estimated to be approximately $5.5-6.0 \mathrm{Pg} \mathrm{CO}_{2}$ eq. $\mathrm{yr}^{-1}$ by 2030 (Smith et al., 2008). However, the release of $\mathrm{CO}_{2}$ during the manufacturing and application of $\mathrm{N}$ fertilizer to crops and from fuel used in machines for farm operations can counteract these mitigation efforts (West and Marland, 2002). Therefore, when determining the GWP of agroecosystems, there is a need to account for all sources of GHG emissions, including the emissions associated with agrochemical input (Ei) and farm operation (Eo) and sinks, e.g., soil organic carbon (SOC) sequestration (Sainju et al., 2014).

Information on the effects of ISSM scenarios on GWP and greenhouse gas intensity (GHGI) of agricultural systems is limited in China (Ma et al., 2013; Liu et al., 2015). The annual rotation of summer rice-upland crop is a dominant cropping system in China. Previous studies were mainly focused on the initial influences of ISSM practices on $\mathrm{CH}_{4}$ and $\mathrm{N}_{2} \mathrm{O}$ emissions, but did not account for the contributions of $\mathrm{CO}_{2}$ emissions from Ei and Eo (Ma et al., 2013; Zhang et al., 2014). In this study, we evaluated GWP and GHGI of rice-wheat crop rotation managed under several scenarios of ISSM by taking $\mathrm{CO}_{2}$ equivalents emissions from all sources and sinks into account for 3 years. We hypothesized that the ISSM strategies would reduce the overall GWP and GHGI compared with local farmers' practice (FP). The specific objectives of this study were to (i) evaluate the effects of different ISSM scenarios on GWP and GHGI; (ii) determine the main sources of GWP and GHGI in a rice-wheat cropping system; and (iii) elucidate the overall performance for each ISSM scenario for different targets to increase grain yields and NUE and reduce GWP and GHGI.

\section{Materials and methods}

\subsection{Experimental site}

A field experiment was conducted at the Changshu agroecological experimental station $\left(31^{\circ} 32^{\prime} 93^{\prime \prime} \mathrm{N}, 120^{\circ} 41^{\prime} 88^{\prime \prime} \mathrm{E}\right)$ in Jiangsu province, China. This is a typical, intensively managed agricultural area where the cropping regime is dominated by a flooded rice (Oryza sativa $\mathrm{L}$.)-drained wheat (Triticum aestivum L.) rotation system. The site is characterized by a subtropical humid monsoon climate, with a mean annual air temperature of $15.6,15.2$ and $15.8^{\circ} \mathrm{C}$ and precipitation of 878,1163 and $984 \mathrm{~mm}$ for 3 years, respectively. The soil of the field is classified as an Anthrosol with a sandy loam texture of $6 \%$ sand $(1-0.05 \mathrm{~mm}), 80 \%$ silt $(0.05-0.001 \mathrm{~mm})$ and $14 \%$ clay $(<0.001 \mathrm{~mm})$, which developed from lacustrine sediment. The major properties of the soil at $0-20 \mathrm{~cm}$ can be described as follows: bulk density, $1.11 \mathrm{~g} \mathrm{~cm}^{-3}$; $\mathrm{pH}, 7.35$; organic matter content, $35.0 \mathrm{~g} \mathrm{~kg}^{-1}$; and total $\mathrm{N}, 2.1 \mathrm{~g} \mathrm{~kg}^{-1}$. The daily mean air temperatures and precipitation during the study period, from 15 June 2011 to 15 June 2014, are given in the Fig. 1.

\subsection{Experimental design and management}

A completely randomized block design was established in 2009 with four replicates of six treatments, including no nitrogen $(\mathrm{NN})$ and FP as controls, and four ISSM scenarios at different chemical $\mathrm{N}$ fertilizer application rates relative to the local FP rate $\left(300 \mathrm{~kg} \mathrm{Nha}^{-1}\right)$, namely ISSM-N1 $(25 \%$ reduction), ISSM-N2 (10\% reduction), ISSM-N3 (FP rate) and ISSM-N4 ( $25 \%$ increase). The designed ISSM scenarios (only for rice but not for wheat) included a redesigned split $\mathrm{N}$ fertilizer application, a balanced fertilizer application that included sodium silicate, zinc sulfate, rapeseed cake $(\mathrm{C} / \mathrm{N}=8)$ providing an additional $112.5 \mathrm{~kg} \mathrm{Nha}^{-1}$, and additional phosphorus and potassium, and different transplanting densities, used as the main techniques for improving rice yield and agronomic NUE. The agronomic NUE was calculated as the difference in grain yield between the plots that received $\mathrm{N}$ application and the $\mathrm{NN}$ plot, divided by the total $\mathrm{N}$ rate which included chemical $\mathrm{N}$ fertilizer and $\mathrm{N}$ supplied from rapeseed cake in the ISSM-N3 and ISSM-N4 scenarios. The details of the fertilizer applications, irrigation and field management practices of the six different treatments are presented in Table 1. Further information was described previously (Zhang et al., 2014). Each plot was $6 \mathrm{~m} \times 7 \mathrm{~m}$ in size with an independent drainage/irrigation system.

One midseason drainage (about 1 week) and final drainage before harvest were used during the rice-growing season, whereas the plots only received precipitation during the wheat-growing season. The $\mathrm{N}$ fertilizer was split into a $6: 2: 0: 2$ or $5: 1: 2: 2$ ratio of basal fertilizer and topdressing for the rice crop and a $6: 1: 3$ ratio for the wheat crop. Phosphorus (P), silicon $(\mathrm{Si})$ and zinc $(\mathrm{Zn})$ were all applied 


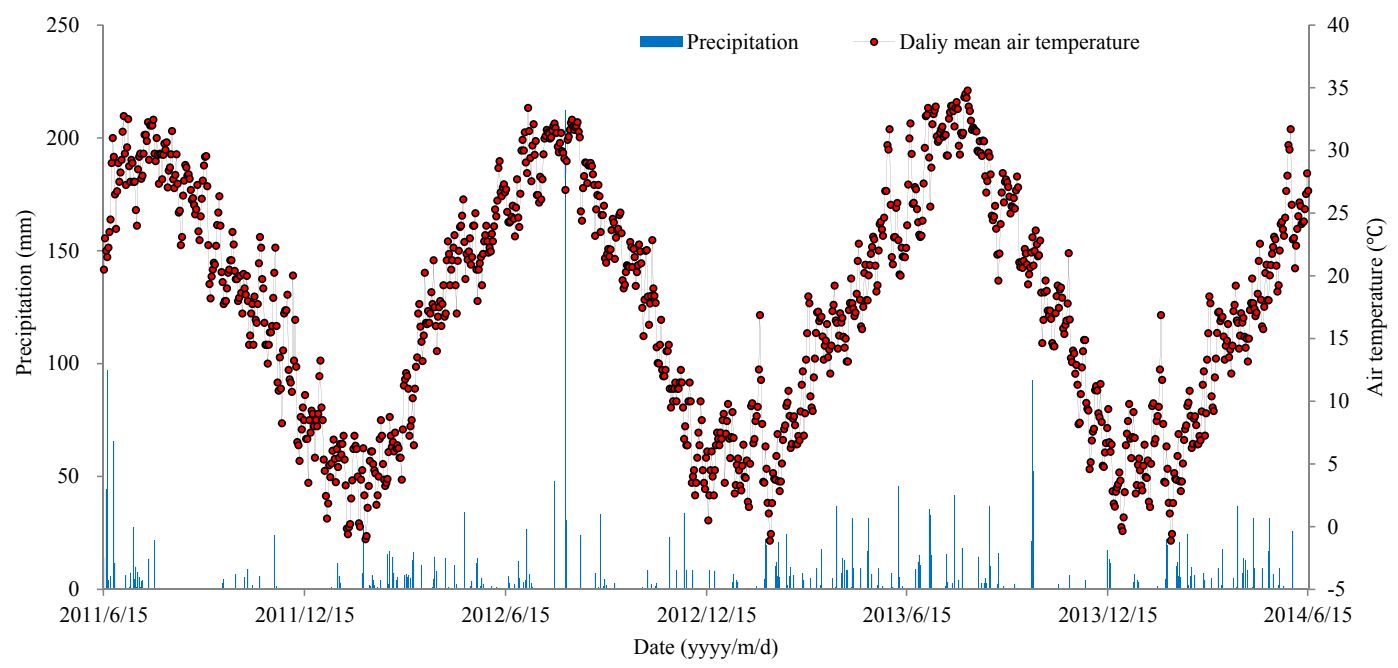

Figure 1. Daily mean air temperature and precipitation during the rice-wheat rotation in 2011-2014 in Changshu, China.

as basal fertilizers for both crops, and rapeseed cake manure was applied for the rice crop. Potassium (K) was added as a split $(1: 1)$ application to the rice crop and all were added as basal fertilizer for the wheat crop. The basal fertilization occurred at the time of rice transplanting and wheat seeding. The topdressing was applied at the tillering, elongation and panicle stages of the rice crop and at the seedling establishment and elongation stages of the wheat crop. Above-ground biomass including crop grains and straws were removed out of the fields for all the treatments.

\subsection{Gas sampling and measurements}

We measured the $\mathrm{CH}_{4}$ and $\mathrm{N}_{2} \mathrm{O}$ emissions from each plot of the field experiment over five annual cycles from the 2009 rice-growing season to the 2014 wheat-growing season. The initial 2-year measurements during the 2009-2011 rice-wheat rotational systems were described in our previous study (Ma et al., 2013). Emissions were measured manually using the static opaque chamber method. Each replicate plot was equipped with a chamber with a size of $50 \mathrm{~cm} \times 50 \mathrm{~cm} \times 50 \mathrm{~cm}$ or $50 \mathrm{~cm} \times 50 \mathrm{~cm} \times 110 \mathrm{~cm}$, depending on the crop growth and plant height. The chamber was placed on a fixed PVC frame in each plot and wrapped with a layer of sponge and aluminum foil to minimize air temperature changes inside the chamber during the period of sampling. Gas samples were collected from 09:00 to 11:00 using an airtight syringe with a $20 \mathrm{~mL}$ volume at intervals of 10 $\min (0,10,20$ and $30 \mathrm{~min}$ after chamber closure). The fluxes were measured once a week and more frequently after fertilizer application or a change in soil moisture.

The gas samples were analyzed for $\mathrm{CH}_{4}$ and $\mathrm{N}_{2} \mathrm{O}$ concentrations using a gas chromatograph (Agilent 7890A, Shanghai, China) equipped with two detectors. Methane was detected using a hydrogen flame ionization detector (FID), and
$\mathrm{N}_{2} \mathrm{O}$ was detected using an electron capture detector (ECD). Argon-methane (5\%) and $\mathrm{N}_{2}$ were used as the carrier gas at a flow rate of $40 \mathrm{~mL} \mathrm{~min}^{-1}$ for $\mathrm{N}_{2} \mathrm{O}$ and $\mathrm{CH}_{4}$ analysis, respectively. The temperatures for the column and an ECD were maintained at 40 and $300^{\circ} \mathrm{C}$, respectively. The oven and FID were operated at 50 and $300^{\circ} \mathrm{C}$, respectively. The $\mathrm{CH}_{4}$ and $\mathrm{N}_{2} \mathrm{O}$ fluxes were calculated using a linear increase in the two gas concentrations over time as described by Jia et al. (2012).

\subsection{Topsoil organic carbon sequestration measurements}

To measure the organic carbon content of the topsoil as described by Zhang et al. (2014), soil samples were collected after the wheat harvest in 2009 and 2014 from all experimental plots at a plowing depth of $0-20 \mathrm{~cm}$. The soil organic carbon sequestration rates (SOCSRs) were calculated as follows (Liu et al., 2015):

$$
\begin{aligned}
\operatorname{SOCSR}\left(\mathrm{tCha}^{-1} \mathrm{yr}^{-1}\right) & =\left(\mathrm{SOC}_{t}-\mathrm{SOC}_{0}\right) / T \times \gamma \\
& \times\left(1-\delta_{2} \mathrm{~mm} / 100\right) \times 20 \times 10^{-1} .
\end{aligned}
$$

In Eq. (1), $\mathrm{SOC}_{t}\left(\mathrm{~g} \mathrm{C} \mathrm{kg}^{-1}\right)$ and $\mathrm{SOC}_{0}\left(\mathrm{~g} \mathrm{C} \mathrm{kg}^{-1}\right)$ are the SOC contents measured in the soils sampled after the wheat was harvested in 2014 and 2009, respectively. $T$ refers to the experimental period (yr). $\gamma$ and $\delta_{2 \mathrm{~mm}}$ are the average bulk density and the gravel content $(>2 \mathrm{~mm})$ of the topsoil $(0$ $20 \mathrm{~cm}$ ), respectively.

\subsection{GWP and GHGI measurements}

To better understand the overall GHG impact of the ricewheat crop rotation managed under different ISSM scenarios, the GWP and GHGI were calculated using the following 


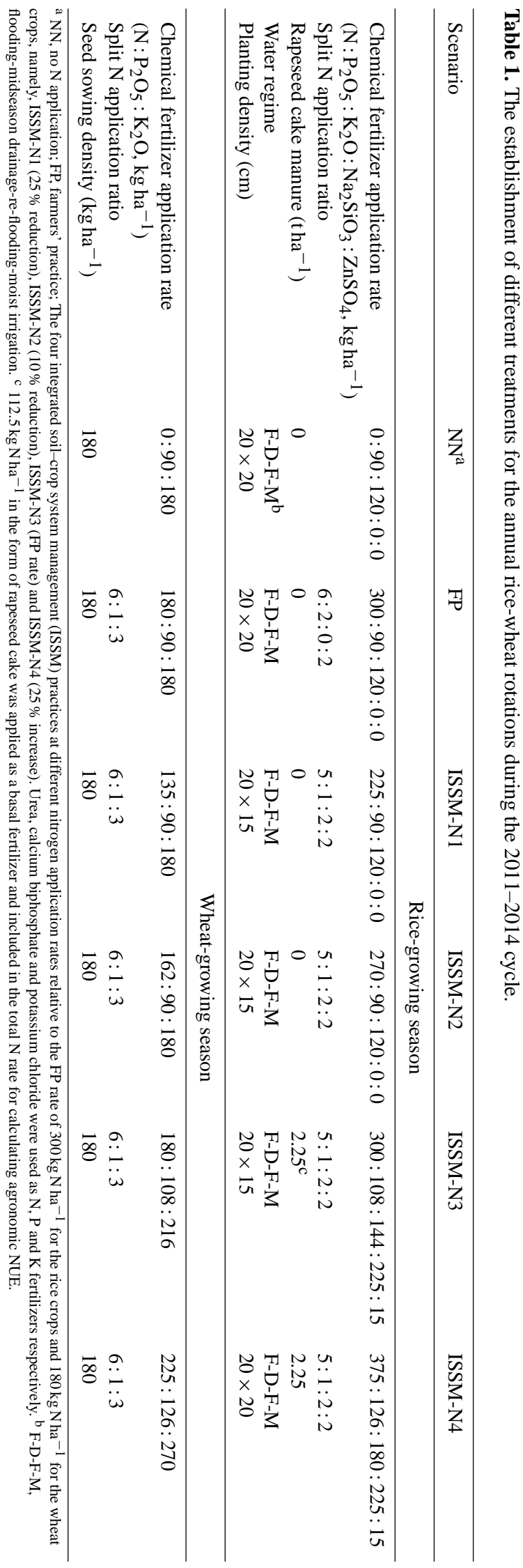

equations (Myhre et al., 2013):

$$
\begin{array}{r}
\text { GWP }\left(\mathrm{kg} \mathrm{CO}_{2} \text { eq. } \mathrm{ha}^{-1} \mathrm{yr}^{-1}\right)=28 \times \mathrm{CH}_{4}+265 \times \mathrm{N}_{2} \mathrm{O} \\
+\mathrm{Ei}+\mathrm{Eo}-44 / 12 \times \mathrm{SOCSR}^{-1} \\
\text { GHGI }\left(\mathrm{kg} \mathrm{CO}_{2} \text { eq. kg }{ }^{-1} \text { grain yield } \mathrm{yr}^{-1}\right)=\mathrm{GWP}_{\text {grain yield }}{ }^{-1} .
\end{array}
$$

In Eq. (2), Ei $\quad\left(\mathrm{kg} \mathrm{CO}_{2}\right.$ eq. $\left.\mathrm{ha}^{-1} \mathrm{yr}^{-1}\right), \quad$ Eo $\left(\mathrm{kgCO}_{2}\right.$ eq. $\left.\mathrm{ha}^{-1} \mathrm{yr}^{-1}\right)$ and SOCSR $\left(\mathrm{kgCha}^{-1} \mathrm{yr}^{-1}\right)$ represent $\mathrm{CO}_{2}$ equivalent emissions from the agrochemical inputs, farm operations and soil organic carbon sequestration rate, respectively. The global warming potential of $1 \mathrm{~kg} \mathrm{CH}_{4}$ and $1 \mathrm{~kg} \mathrm{~N}_{2} \mathrm{O}$ are 28 and $265 \mathrm{~kg} \mathrm{CO}_{2}$ equivalents respectively (without inclusion of climate-carbon feedbacks), based on a 100-year timescale (Myhre et al., 2013). 12 and 44 refers to molecular weights of $\mathrm{C}$ and $\mathrm{CO}_{2}$, respectively. The grain yield is expressed as the air-dried grain yield.

Therefore, the GWP of the cropland ecosystem equals the total $\mathrm{CO}_{2}$ equivalent emissions minus the SOC change per unit land area. In addition to $\mathrm{CH}_{4}$ and $\mathrm{N}_{2} \mathrm{O}$ emissions, we considered $\mathrm{CO}_{2}$ equivalent emissions associated with the use of agrochemical input (Ei), such as the manufacture and transportation of the N, P and $\mathrm{K}$ fertilizers (Snyder et al., 2009), and farm operation (Eo), such as the water used for irrigation (Zhang et al., 2013) and diesel fuel (Huang et al., 2013a). The $\mathrm{CO}_{2}$ equivalent emissions of $\mathrm{N}$ fertilizer were calculated as the mean value of the $\mathrm{C}$ emis-

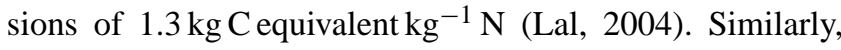
the $\mathrm{CO}_{2}$ equivalent for irrigation was calculated from the total amount of water used during the rice-growing season; the coefficient for the $\mathrm{C}$ cost was $5.16\left(\mathrm{~kg} \mathrm{C}\right.$ eq. $\mathrm{cm}^{-1} \mathrm{ha}^{-1}$ ) originated from the value of $257.8 \mathrm{~kg} \mathrm{C}$ eq. $\mathrm{ha}^{-1}$ for a $50 \mathrm{~cm}$ of irrigation provided by Lal (2004). The $\mathrm{CO}_{2}$ equivalents of other $\mathrm{Ei}$ ( $\mathrm{P}$ and $\mathrm{K}$ fertilization, manure, herbicide, pesticide and fungicide applications) and Eo (tillage, planting, harvest and threshing) were recorded and also estimated by coefficients provided by Lal (2004) since no specific coefficients were available for local conditions. We collected the data specific to China's fertilizer manufacture and consumption, and obtained the $\mathrm{C}$ emission coefficients to be 0.07 and $0.1 \mathrm{kgC}$ eq. $\mathrm{kg}^{-1}$ of active ingredients for $\mathrm{Si}$ and $\mathrm{Zn}$ fertilizer, respectively. The $\mathrm{C}$ emission factor for these farm operations depends on diesel used as fuel or electricity. Chemical fertilizer was hand-broadcasted for each fertilization event. Detailed information of each Ei and Eo component for rice and wheat crop seasons are presented in Table 2.

\subsection{Statistical analysis}

Repeated-measures multivariate analysis of variance (MANOVA) and linear relationships were determined using JMP 7.0, ver. 7.0 (SAS Institute, USA, 2007). The $F$ test was applied to determine whether there were significant differences among practices, years and their interaction at $P<0.05$. One-way analysis of variance was conducted to 


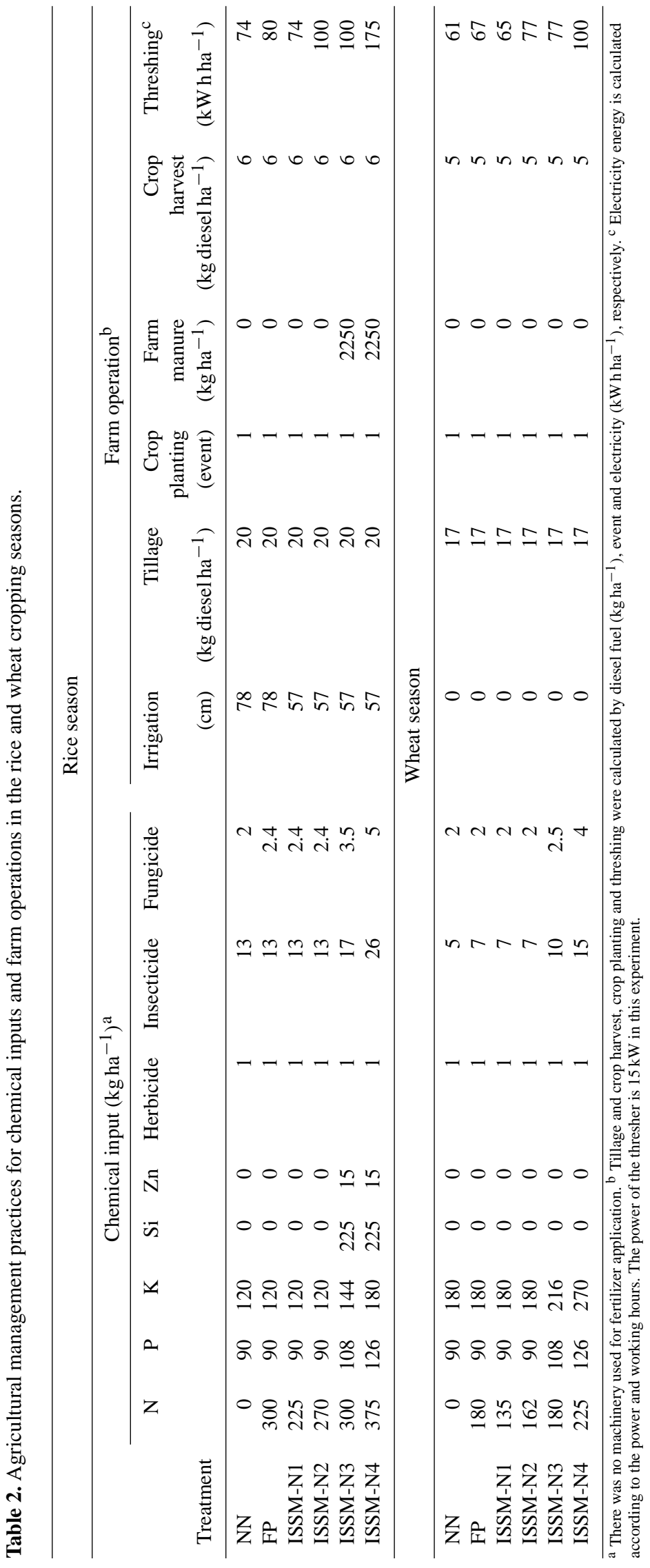

compare the cumulative fluxes of $\mathrm{CH}_{4}$ and $\mathrm{N}_{2} \mathrm{O}$, and grain yield among the different treatments. Tukey's Honestly Significant Difference (HSD) test was used to determine whether significant differences occurred between the treatments at a level of $P<0.05$. Normal distribution and variance uniformity were checked and all data were consistent with the variance uniformity $(P>0.05)$ within each group. The results are presented as the means and standard deviation (mean $\pm \mathrm{SD}, n=4$ ).

\section{Results}

\subsection{Crop production and agronomic NUE}

During the three cropping rotations from 2011 to 2014, the rice and wheat yields varied significantly among the treatments (Table 3 ). The grain yields ranged from 5.83 to $12.11 \mathrm{tha}^{-1}$ for rice and 1.75 to $6.14 \mathrm{tha}^{-1}$ for wheat. On average over the three cycles, the annual rice yield of the FP was significantly lower than that of the ISSM scenarios of ISSM-N1, ISSM-N2, ISSM-N3 and ISSM-N4. Compared with the FP, rice grain yields increased by 10 and $16 \%$ for the ISSM-N1 and ISSM-N2 scenarios, respectively, i.e., with the lower $\mathrm{N}$ input, by $28 \%$ for the ISSM-N3 scenario with the same $\mathrm{N}$ input and by $41 \%$ for the ISSM-N4 scenario with the highest $\mathrm{N}$ input. However, we did not observe any significant increases in the wheat-grain yields compared with the FP except for the ISSM-N4 scenario. Statistical analysis indicated that rice and wheat yields from the 3 years were not significantly influenced by the interaction of cultivation patterns and cropping year (Table 4).

The agronomic NUE for the rice and wheat of the fertilized plots ranged from 9.2 to 16.1 and 19.5 to $24.7 \mathrm{~kg}$ grain $\mathrm{kg} \mathrm{N}^{-1}$, respectively (Fig. 2). The higher NUE in the wheat season was mainly due to the relatively lower $\mathrm{N}$ fertilizer $(40 \%)$ rates used for wheat compared with that for rice. As expected, the rice agronomic NUE significantly increased by $75,67,35$ and $40 \%$ for the ISSM-N1, ISSM-N2, ISSM-N3 and ISSM-N4 scenarios, respectively, compared with the FP (Fig. 2). For the wheat crop, the agronomic NUE increased by 12 and $14 \%$ in the ISSM-N1 and ISSM-N2 scenarios, respectively, and slightly decreased in the ISSM-N3 and ISSM-N4 scenarios compared with the FP, mainly because the current ISSM strategy was only designed for rice and not wheat production.

\section{2 $\quad \mathrm{CH}_{4}$ and $\mathrm{N}_{2} \mathrm{O}$ emissions}

All plots showed similar $\mathrm{CH}_{4}$ emission patterns, being a source in the rice season and negligible in the wheat season (Fig. 3). During the three annual rice-wheat rotations from 2011 to 2014, the $\mathrm{CH}_{4}$ fluxes ranged from -3.89 to $99.67 \mathrm{mg} \mathrm{C} \mathrm{m}^{-2} \mathrm{~h}^{-1}$. The seasonal $\mathrm{CH}_{4}$ emissions varied significantly among the treatments during the rice-growing season (Table 4, Fig. 3). No significant difference was found 
Table 3. Seasonal $\mathrm{CH}_{4}$ and $\mathrm{N}_{2} \mathrm{O}$ emissions, and yields during rice and wheat cropping seasons in the three cycles of $2011-2014$.

\begin{tabular}{|c|c|c|c|c|c|c|}
\hline \multirow[b]{2}{*}{ Treatment } & \multicolumn{3}{|c|}{ Rice season } & \multicolumn{3}{|c|}{ Wheat season } \\
\hline & $\begin{array}{r}\mathrm{CH}_{4} \\
\left(\mathrm{~kg} \mathrm{Cha}^{-1}\right)\end{array}$ & $\begin{array}{r}\mathrm{N}_{2} \mathrm{O} \\
\left(\mathrm{kg} \mathrm{Nha}^{-1}\right)\end{array}$ & $\begin{array}{r}\text { Yield } \\
\left(\mathrm{tha}^{-1}\right)\end{array}$ & $\begin{array}{r}\mathrm{CH}_{4} \\
\left(\mathrm{kgCha}^{-1}\right)\end{array}$ & $\begin{array}{r}\mathrm{N}_{2} \mathrm{O} \\
\left(\mathrm{kg} \mathrm{Nha}^{-1}\right)\end{array}$ & $\begin{array}{r}\text { Yield } \\
\left(\mathrm{tha}^{-1}\right)\end{array}$ \\
\hline \multicolumn{7}{|l|}{2011} \\
\hline $\mathrm{NN}$ & $153 \pm 10.8 c$ & $0.03 \pm 0.05 c$ & $5.85 \pm 0.08 f$ & $-0.48 \pm 0.63 \mathrm{a}$ & $0.45 \pm 0.09 \mathrm{~d}$ & $1.74 \pm 0.18 \mathrm{~d}$ \\
\hline FP & $266 \pm 25.3 b$ & $0.11 \pm 0.08 \mathrm{c}$ & $8.38 \pm 0.35 \mathrm{e}$ & $-0.48 \pm 1.86 \mathrm{a}$ & $1.43 \pm 0.19 b$ & $5.67 \pm 0.20 b$ \\
\hline ISSM-N1 & $212 \pm 30.3 b c$ & $0.08 \pm 0.03 c$ & $9.27 \pm 0.26 \mathrm{~d}$ & $0.78 \pm 0.97 \mathrm{a}$ & $0.65 \pm 0.11 \mathrm{~cd}$ & $5.05 \pm 0.16 \mathrm{c}$ \\
\hline ISSM-N2 & $220 \pm 32.5 b c$ & $0.17 \pm 0.11 b c$ & $9.79 \pm 0.44 c$ & $2.25 \pm 2.07 \mathrm{a}$ & $0.80 \pm 0.06 c$ & $5.71 \pm 0.18 b$ \\
\hline ISSM-N3 & $518 \pm 58.9 \mathrm{a}$ & $0.38 \pm 0.15 \mathrm{ab}$ & $10.81 \pm 0.26 b$ & $0.04 \pm 3.23 \mathrm{a}$ & $1.40 \pm 0.10 \mathrm{~b}$ & $5.31 \pm 0.26 b c$ \\
\hline ISSM-N4 & $561 \pm 50.9 \mathrm{a}$ & $0.37 \pm 0.07 \mathrm{a}$ & $11.76 \pm 0.24 \mathrm{a}$ & $-0.09 \pm 1.40 \mathrm{a}$ & $1.93 \pm 0.09 \mathrm{a}$ & $6.15 \pm 0.15 a$ \\
\hline \multicolumn{7}{|l|}{2012} \\
\hline $\mathrm{NN}$ & $149 \pm 25.8 \mathrm{~d}$ & $0.13 \pm 0.10 \mathrm{c}$ & $5.80 \pm 0.22 f$ & $-4.32 \pm 7.29 \mathrm{a}$ & $0.65 \pm 0.09 \mathrm{~d}$ & $1.73 \pm 0.11 \mathrm{c}$ \\
\hline FP & $239 \pm 34.5 c$ & $0.33 \pm 0.11 b c$ & $8.72 \pm 0.62 \mathrm{e}$ & $4.85 \pm 10.30 \mathrm{a}$ & $2.13 \pm 0.43 \mathrm{ab}$ & $5.64 \pm 0.34 \mathrm{ab}$ \\
\hline ISSM-N1 & $226 \pm 30.4 \mathrm{~cd}$ & $0.27 \pm 0.07 b c$ & $9.43 \pm 0.34 d$ & $1.46 \pm 6.38 \mathrm{a}$ & $1.39 \pm 0.14 c$ & $4.94 \pm 0.38 b$ \\
\hline ISSM-N2 & $228 \pm 32.6 \mathrm{~cd}$ & $0.38 \pm 0.29 b c$ & $9.99 \pm 0.50 \mathrm{c}$ & $-1.02 \pm 0.84 \mathrm{a}$ & $1.77 \pm 0.38 b c$ & $5.78 \pm 0.59 \mathrm{ab}$ \\
\hline ISSM-N3 & $431 \pm 26.8 b$ & $0.52 \pm 0.16 \mathrm{ab}$ & $10.92 \pm 0.61 b$ & $2.45 \pm 8.35 \mathrm{a}$ & $2.19 \pm 0.24 a b$ & $5.39 \pm 0.39 \mathrm{ab}$ \\
\hline ISSM-N4 & $536 \pm 58.7 \mathrm{a}$ & $0.78 \pm 0.13 \mathrm{a}$ & $12.24 \pm 0.60 \mathrm{a}$ & $5.91 \pm 6.18 \mathrm{a}$ & $2.61 \pm 0.42 \mathrm{a}$ & $6.10 \pm 0.49 a$ \\
\hline \multicolumn{7}{|l|}{2013} \\
\hline $\mathrm{NN}$ & $101 \pm 39.2 b$ & $0.16 \pm 0.09 b$ & $5.84 \pm 0.15 f$ & $-1.45 \pm 1.34 \mathrm{a}$ & $0.35 \pm 0.06 c$ & $1.80 \pm 0.03 \mathrm{c}$ \\
\hline FP & $141 \pm 25.2 b$ & $0.43 \pm 0.39 \mathrm{ab}$ & $8.67 \pm 0.26 \mathrm{e}$ & $-3.70 \pm 1.76 \mathrm{a}$ & $0.80 \pm 0.20 \mathrm{ab}$ & $5.70 \pm 0.30 \mathrm{ab}$ \\
\hline ISSM-N1 & $135 \pm 15.7 b$ & $0.19 \pm 0.16 \mathrm{ab}$ & $9.66 \pm 0.29 d$ & $-1.00 \pm 1.61 \mathrm{a}$ & $0.49 \pm 0.16 b c$ & $5.15 \pm 0.20 b$ \\
\hline ISSM-N2 & $129 \pm 32.2 b$ & $0.26 \pm 0.13 \mathrm{ab}$ & $10.15 \pm 0.07 \mathrm{c}$ & $-0.79 \pm 1.60 \mathrm{a}$ & $0.69 \pm 0.24 \mathrm{abc}$ & $5.80 \pm 0.18 \mathrm{ab}$ \\
\hline ISSM-N3 & $256 \pm 45.6 \mathrm{a}$ & $0.59 \pm 0.42 \mathrm{ab}$ & $11.14 \pm 0.10 \mathrm{~b}$ & $-0.62 \pm 1.14 \mathrm{a}$ & $0.71 \pm 0.10 \mathrm{ab}$ & $5.51 \pm 0.33 \mathrm{ab}$ \\
\hline ISSM-N4 & $304 \pm 22.3 \mathrm{a}$ & $0.74 \pm 0.40 \mathrm{a}$ & $12.34 \pm 0.16 \mathrm{a}$ & $0.55 \pm 1.68 \mathrm{a}$ & $1.02 \pm 0.11 \mathrm{a}$ & $6.19 \pm 0.63 a$ \\
\hline \multicolumn{7}{|c|}{ Average $2011-2013^{\mathrm{a}}$} \\
\hline $\mathrm{NN}^{\mathrm{b}}$ & $135 \pm 19.6 \mathrm{~d}$ & $0.11 \pm 0.05 \mathrm{c}$ & $5.83 \pm 0.04 f$ & $-2.08 \pm 1.89 \mathrm{a}$ & $0.48 \pm 0.07 \mathrm{~d}$ & $1.75 \pm 0.04 \mathrm{~d}$ \\
\hline $\mathrm{FP}^{\mathrm{b}}$ & $215 \pm 19.9 c$ & $0.29 \pm 0.13 b c$ & $8.59 \pm 0.25 \mathrm{e}$ & $0.22 \pm 3.96 \mathrm{a}$ & $1.45 \pm 0.24 b$ & $5.67 \pm 0.16 b$ \\
\hline ISSM-N $1^{b}$ & $191 \pm 19.2 \mathrm{c}$ & $0.18 \pm 0.06 \mathrm{c}$ & $9.45 \pm 0.18 \mathrm{~d}$ & $0.42 \pm 2.77 \mathrm{a}$ & $0.84 \pm 0.08 \mathrm{c}$ & $5.04 \pm 0.08 \mathrm{c}$ \\
\hline ISSM-N $2^{b}$ & $192 \pm 11.6 c$ & $0.27 \pm 0.12 b c$ & $9.98 \pm 0.25 c$ & $0.15 \pm 0.58 \mathrm{a}$ & $1.08 \pm 0.12 \mathrm{c}$ & $5.76 \pm 0.22 \mathrm{ab}$ \\
\hline ISSM-N $3^{b}$ & $402 \pm 23.8 b$ & $0.50 \pm 0.16 \mathrm{ab}$ & $10.95 \pm 0.13 b$ & $0.63 \pm 3.51 \mathrm{a}$ & $1.43 \pm 0.05 b$ & $5.40 \pm 0.16 b c$ \\
\hline ISSM-N $4^{b}$ & $467 \pm 39.2 \mathrm{a}$ & $0.68 \pm 0.15 \mathrm{a}$ & $12.11 \pm 0.28 \mathrm{a}$ & $2.12 \pm 2.57 \mathrm{a}$ & $1.85 \pm 0.16 \mathrm{a}$ & $6.14 \pm 0.35 a$ \\
\hline
\end{tabular}

${ }^{\mathrm{a}}$ Mean $\pm \mathrm{SD}$, different lower case letters within the same column for each item indicate significant differences at $P<0.05$ according to Tukey's multiple range test. ${ }^{\mathrm{b}}$ See Table 1 for treatment codes.

between the FP, ISSM-N1 and ISSM-N2 plots. Temporal variation was significant during the three cycles (Table 4 , $P<0.001$ ). Averaged across years, the $\mathrm{CH}_{4}$ emission was greater in the ISSM-N3 and ISSM-N4 plots than in the NN, FP, ISSM-N1 and ISSM-N2 plots (Table 3, $P<0.05$ ). However, compared with the NN plots, the FP, ISSM-N1 and ISSM-N2 plots with inorganic fertilizer application resulted in increased $\mathrm{CH}_{4}$ emission rates of 59.9, 41.9 and $43.0 \%$, respectively, averaged over the rice-growing seasons. The $\mathrm{CH}_{4}$ emission rates were further enhanced by $198.5 \%$ in the ISSM-N3 plots and by $246.7 \%$ in the ISSM-N4 plots.

The annual $\mathrm{N}_{2} \mathrm{O}$ fluxes varied from -33.1 to $647.5 \mu \mathrm{g} \mathrm{N} \mathrm{N}_{2} \mathrm{O}-\mathrm{N} \mathrm{m}^{-2} \mathrm{~h}^{-1}$, with most $\mathrm{N}_{2} \mathrm{O}$ emissions occurring during the wheat-growing season after fertilization events, and several small emission peaks during the rice-growing season (Fig. 4). With respect to the $\mathrm{N}$ application effect, the annual cumulative $\mathrm{N}_{2} \mathrm{O}$ emissions for all four ISSM scenarios were significantly higher than that in NN $(P<0.05)$. Relative to the FP plot, the ISSM-N1 and ISSM-N2 scenarios decreased the annual $\mathrm{N}_{2} \mathrm{O}$ emissions by an average of 41 and $22 \%$, respectively (Table 3 ). The ISSM-N4 scenario significantly increased the cumulative $\mathrm{N}_{2} \mathrm{O}$ emissions by $46 \%(P<0.05)$ because this system received highest inorganic $\mathrm{N}$ fertilizer $(25 \%$ higher than that in FP) and additional $\mathrm{N}$ via manure application compared to the FP, although there was no significant difference between the ISSM-N3 and FP plots. 
Table 4. Repeated-measures analysis of variance (MANOVA) for the effects of cultivation patterns (P) and cropping year (Y) on mean $\mathrm{CH}_{4}$ and $\mathrm{N}_{2} \mathrm{O}$ emissions, and mean rice and wheat grain yields in the 2011-2014 cycle.

\begin{tabular}{|c|c|c|c|c|c|}
\hline Crop season & Source & df & $\begin{array}{l}\mathrm{CH}_{4} \\
\left(\mathrm{kgCha}^{-1}\right)\end{array}$ & $\begin{array}{l}\mathrm{N}_{2} \mathrm{O} \\
\left(\mathrm{kg} \mathrm{Nha}^{-1}\right)\end{array}$ & $\begin{array}{l}\text { Yield } \\
\left(\text { tha }^{-1}\right)\end{array}$ \\
\hline \multirow[t]{5}{*}{ Rice } & Between subjects & & & & \\
\hline & $\mathrm{P}$ & 5 & $35.3^{* * *}$ & $3.71^{* * *}$ & $123^{* * *}$ \\
\hline & Within subjects & & & & \\
\hline & $\mathrm{Y}$ & 2 & $20.7^{* * *}$ & $0.88^{* *}$ & $1.15^{* *}$ \\
\hline & $\mathrm{P} \times \mathrm{Y}$ & 10 & $6.73^{* * *}$ & 0.15 & 0.37 \\
\hline \multirow[t]{5}{*}{ Wheat } & Between subjects & & & & \\
\hline & $\mathrm{P}$ & 5 & 0.26 & $14.8^{* * *}$ & $76.3^{* * *}$ \\
\hline & Within subjects & & & & \\
\hline & $\mathrm{Y}$ & 2 & $0.55^{*}$ & $15.1^{* * *}$ & 0.08 \\
\hline & $\mathrm{P} \times \mathrm{Y}$ & 10 & 0.83 & $4.39^{* * *}$ & 0.05 \\
\hline \multirow[t]{5}{*}{ Rice-wheat } & Between subjects & & & & \\
\hline & $\mathrm{P}$ & 5 & $37.2^{* * *}$ & $24.2^{* * *}$ & $153^{* * *}$ \\
\hline & Within subjects & & & & \\
\hline & $\mathrm{Y}$ & 2 & $20.5^{* * *}$ & $5.83^{* * *}$ & $0.70^{*}$ \\
\hline & $\mathrm{P} \times \mathrm{Y}$ & 10 & $6.50^{* * *}$ & 1.11 & 0.17 \\
\hline
\end{tabular}

$\mathrm{df}-$ degrees of freedom, ${ }^{*} P<0.05,{ }^{* *} P<0.01$, and ${ }^{* * *} P<0.001$ represent significant at the $0.05,0.01$ and 0.001 probability level, respectively.

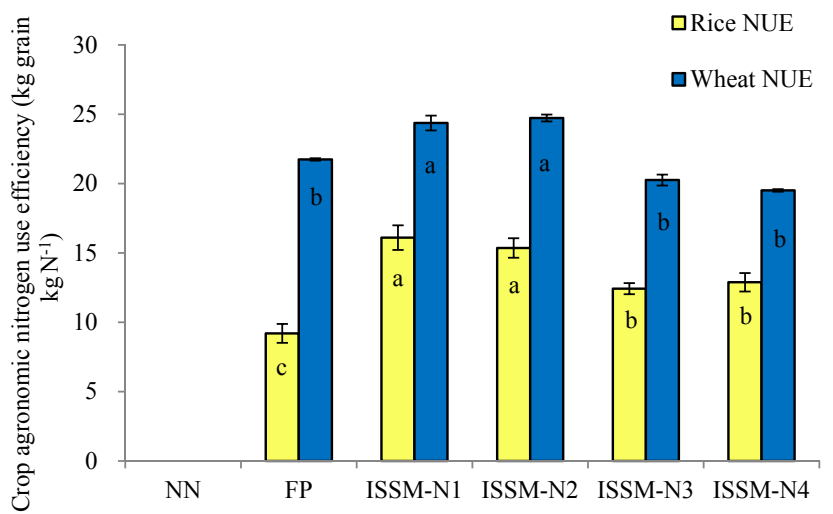

Figure 2. Rice and wheat agronomic nitrogen use efficiency (NUE) in 2011-2014 in Changshu, China. Different letters indicate a significant difference between treatments $(p<0.05)$. See Table 1 for treatment codes.

\subsection{Annual GWP and GHGI}

Based on the perspective of the carbon footprint, we included the GHG emissions associated with all of the inputs (Ei and Eo), and SOC sequestration was expressed as $\mathrm{kg}$ $\mathrm{CO}_{2}$ eq. ha ${ }^{-1} \mathrm{yr}^{-1}$. The $\mathrm{CO}_{2}$ equivalent emissions associated with $\mathrm{Ei}$ and Eo are presented in Table 5. The $\mathrm{CO}_{2}$ equivalents rates from $\mathrm{N}$ fertilizer dominated not only the chemical input section (67-75\% of Ei) but also the total $\mathrm{CO}_{2}$ equivalents from agricultural management $(45-50 \%$ of the sum of the Ei and Eo). Irrigation was the second largest source of $\mathrm{CO}_{2}$ equivalents associated with agricultural management

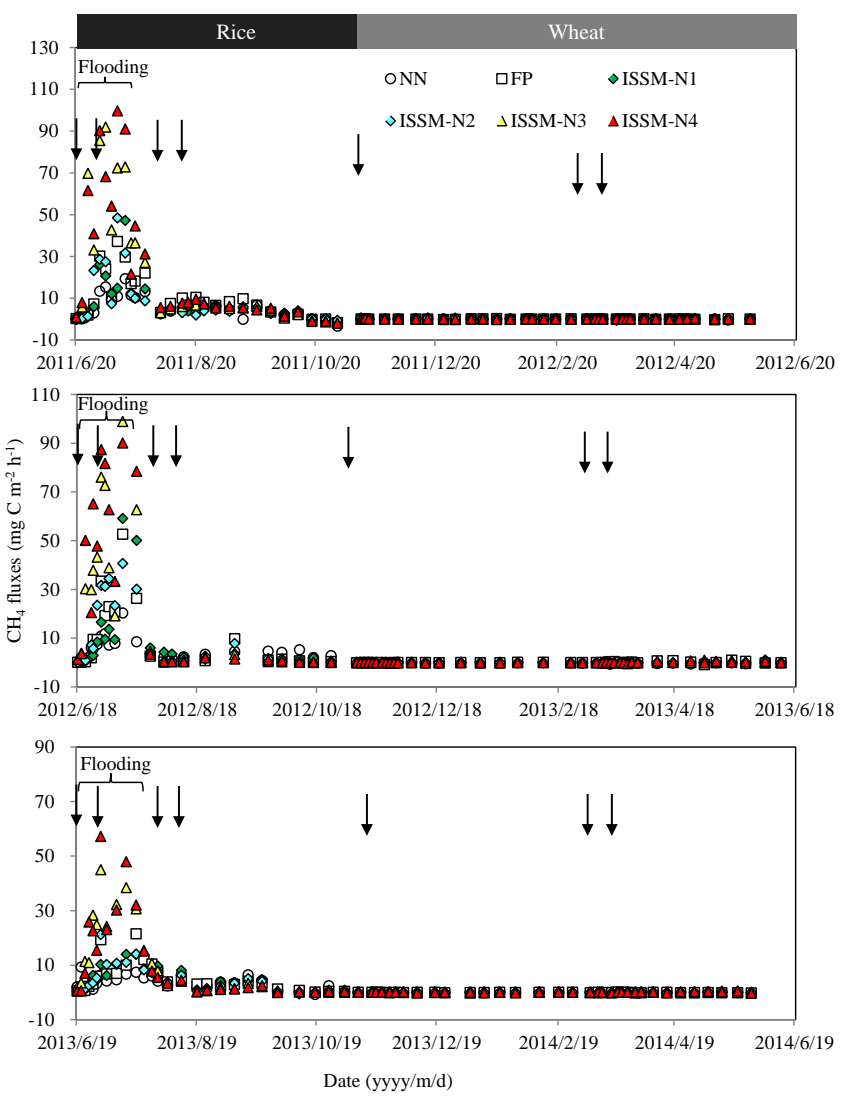

Figure 3. Seasonal variation of methane $\left(\mathrm{CH}_{4}\right)$ fluxes from the ricewheat rotation cropping systems from 2011 to 2014 . The black and gray part in the figure separates different grain growth periods. See Table 1 for treatment codes. The solid arrows indicate fertilization. 
after $\mathrm{N}$ fertilizer (19-31\% of the sum of the Ei and Eo). The GWP ranged from 8425 to $22711 \mathrm{~kg} \mathrm{CO}_{2}$ eq. ha ${ }^{-1} \mathrm{yr}^{-1}$ for the NN and the ISSM-N4 plots, respectively (Table 6). Although fertilized treatments increased the annual $\mathrm{CH}_{4}$ and $\mathrm{N}_{2} \mathrm{O}$ emissions in comparison with the $\mathrm{NN}$ plot, it also increased the SOC sequestration in these cropping systems. Of the main field GHGs that were directly emitted, $\mathrm{CH}_{4}$ accounted for $59-78 \%$ of the GWP in all plots. An increase in the annual SOC content led to a significant decrease in the GWP (contributed 5-9\% decrease of the GWP except in the $\mathrm{NN}$ plot). Concerning the $\mathrm{CO}_{2}$ equivalents from agricultural management practices, emissions associated with Ei (2493-4300 $\mathrm{CO}_{2}$ eq. $\mathrm{ha}^{-1} \mathrm{yr}^{-1}$ ) were higher than those associated with Eo $\left(1296-1708 \mathrm{CO}_{2}\right.$ eq. $\left.\mathrm{ha}^{-1} \mathrm{yr}^{-1}\right)$ in the fertilized plots. There was no significant difference in the annual GWP observed between the FP, ISSM-N1 and ISSMN2 plots (Table 6). Across the 3 years, ISSM-N1 and ISSM$\mathrm{N} 2$ slightly reduced the GWP by 12 and $10 \%$, respectively; however, ISSM-N3 and ISSM-N4 significantly increased the GWP by an average of 55 and $84 \%$, respectively, in comparison with the FP.

The GHGI was used to express the relationship between GWP and grain yield. The GHGIs ( $\mathrm{kg} \mathrm{CO}_{2}$ eq. $\mathrm{t}^{-1}$ grain) in this study ranged from 712 to $1245 \mathrm{~kg} \mathrm{CO}_{2}$ eq. $\mathrm{t}^{-1}$ grain (Table 6). The significant difference in the GHGI of grain was found between the FP and the ISSM strategies. Compared with the FP, ISSM-N1 and ISSM-N2 significantly reduced the GHGI by 14 and $18 \%$, respectively, mainly due to the increased grain yield and SOC sequestration as well as reduced GHG emissions for the ISSM strategies of reasonable $\mathrm{N}$ fertilizer management and suitable planting density. Although $\mathrm{N}$ fertilizer or organic/inorganic combination fertilizer application reduced the SOC losses caused by crop cultivation and increased the grain yields, the GHGIs were generally higher for the ISSM-N3 and ISSM-N4 scenarios than the ISSM-N1 and ISSM-N2 scenarios due to further increases in $\mathrm{CH}_{4}$ and $\mathrm{N}_{2} \mathrm{O}$ emissions.

\section{Discussion}

\subsection{Grain yield and agronomic NUE as affected by ISSM strategies}

Grain yields are directly related to fertilizer management. The MANOVA results indicated that the rice and wheat grain yields were significantly affected by the cultivation strategies (Table $4, P<0.001$ ), which is in agreement with previous results (Chen et al., 2011; Zhang et al., 2011). Compared with the FP, rice yields increased significantly by all four ISSM scenarios (Table 3). However, the wheat grain yield decreased significantly when the $\mathrm{N}$ fertilizer rate was reduced by $25 \%$ (N1 scenario). It has been reported in previous studies that ISSM strategies can effectively improve the rice grain yield (Ma et al., 2013; Liu et al., 2015). First, the

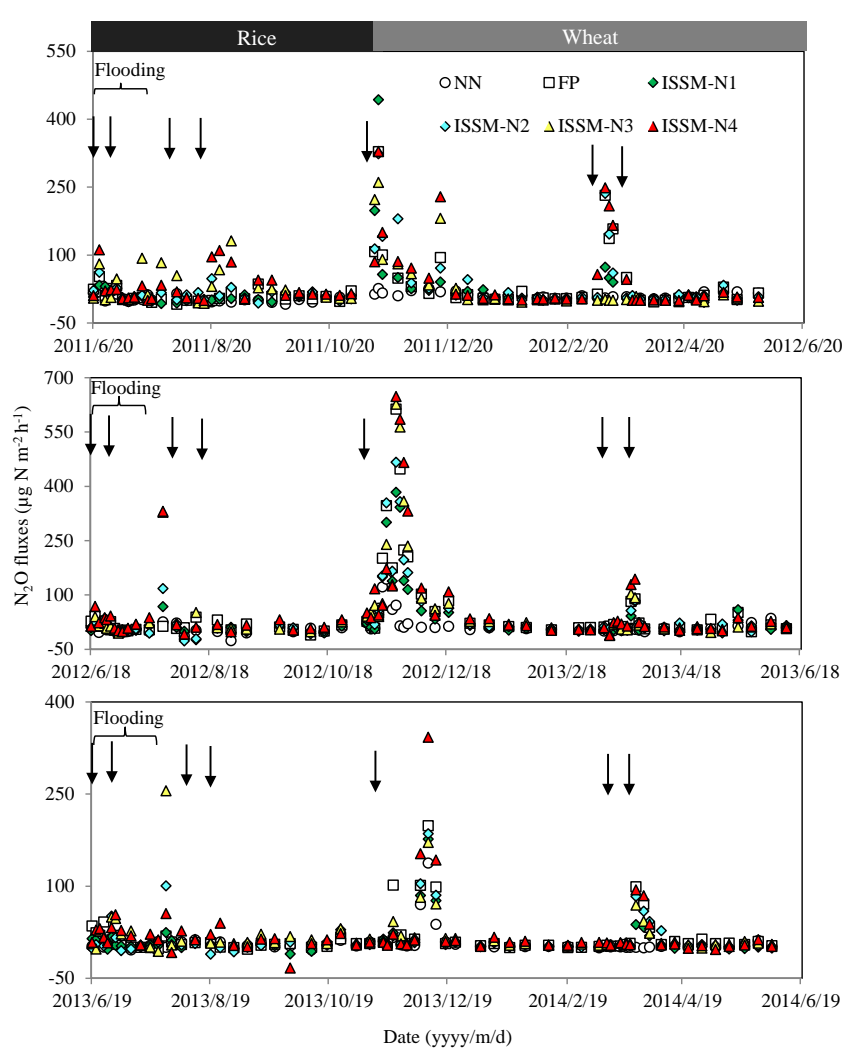

Figure 4. Seasonal variation of nitrous oxide $\left(\mathrm{N}_{2} \mathrm{O}\right)$ fluxes from rice-wheat rotation cropping systems in three annual cycles over the period 2011-2014. The black and gray part in the figure separates different growth periods. See Table 1 for treatment codes. The solid arrows indicate fertilization.

adjusted transplanting density for the ISSM-N1, ISSM-N2 and ISSM-N3 scenarios would produce a positive effect on rice yield by influencing rice colony structure, which agreed with Wu et al. (2005). Second, split application of $\mathrm{N}$ fertilizer to match crop demand in the ISSM-N1, ISSM-N2, ISSM-N3 and ISSM-N4 scenarios would significantly increase agronomic NUE and rice yield which had been reported previously by Liu et al. (2009). In the present study, ISSM-N1 and ISSM-N2 significantly increased annual rice production by 10 and $16 \%$, respectively, in comparison with the FP (Table 3). This finding is consistent with the results of Peng et al. (2006), who reported that a $30 \%$ reduction in the total $\mathrm{N}$ rate during the early vegetative stage did not reduce the yield but slightly increased it when combined with the modified farmers' fertilizer practice. Third, integrated management of three macronutrients, N, P and K, as well as the two micronutrients, $\mathrm{Si}$ and $\mathrm{Zn}$, were considered as essential for sustainable high crop yields. Additional $\mathrm{Si}$ and $\mathrm{Zn}$ fertilizer for the ISSM-N3 and ISSM-N4 scenarios would support better seedling establishment and reduce both biotic and abiotic stress, thus producing higher yields (Wang et al., 2005; Slaton et al., 2005; Kabata-Pendias and Mukherjee, 2007; Hos- 
Table 5. Agricultural management practices for chemical input and farm operation and contributions to carbon dioxide equivalents ( $\mathrm{kg} \mathrm{CO}_{2}$ eq. $\mathrm{ha}^{-1} \mathrm{yr}^{-1}$ ) in the annual rice-wheat rotations from 2011 to 2014 (chemical input and farm operation used in each year were similar except for irrigation water).

\begin{tabular}{|c|c|c|c|c|c|c|c|c|c|c|c|c|c|c|c|c|}
\hline \multirow[t]{3}{*}{ Treatment } & \multicolumn{8}{|c|}{ Chemical input $\left(\mathrm{kg} \mathrm{ha}^{-1}\right)^{\mathrm{a}}$} & \multicolumn{8}{|c|}{ Farm operation $^{\mathrm{c}}$} \\
\hline & \multirow[t]{2}{*}{$\mathrm{N}$} & \multirow[t]{2}{*}{$P$} & \multirow[t]{2}{*}{ K } & \multirow[t]{2}{*}{$\mathrm{Si}$} & \multirow[t]{2}{*}{$\mathrm{Zn}$} & \multirow[t]{2}{*}{ Herbicide } & \multirow[t]{2}{*}{ Insecticide } & \multirow[t]{2}{*}{ Fungicide } & \multicolumn{3}{|c|}{ Irrigation $(\mathrm{cm})^{\mathrm{b}}$} & \multirow{2}{*}{$\begin{array}{r}\text { Tillage } \\
\text { and raking } \\
\left(\mathrm{kg} \mathrm{diesel} \mathrm{ha}^{-1}\right)\end{array}$} & \multirow{2}{*}{$\begin{array}{r}\text { Crop } \\
\text { planting } \\
\text { (event) }\end{array}$} & \multirow{2}{*}{$\begin{array}{r}\text { Farm } \\
\text { manure } \\
\left(\mathrm{kg} \mathrm{ha}^{-1}\right)\end{array}$} & \multirow{2}{*}{$\begin{array}{r}\text { Crop } \\
\text { harvest } \\
\left(\mathrm{kg} \mathrm{diesel} \mathrm{ha}^{-1}\right)\end{array}$} & \multirow{2}{*}{$\begin{array}{r}\text { Threshing } \\
\left(\mathrm{kWhha}^{-1}\right)\end{array}$} \\
\hline & & & & & & & & & 2011 & 2012 & 2013 & & & & & \\
\hline $\mathrm{NN}^{\mathrm{d}}$ & 0 & 180 & 300 & 0 & 0 & 2 & 18 & 4 & 75 & 80 & 80 & 37 & 2 & 0 & 11 & 135 \\
\hline FP & 480 & 180 & 300 & 0 & 0 & 2 & 20 & 4.4 & 75 & 80 & 80 & 37 & 2 & 0 & 11 & 147 \\
\hline ISSM-N1 & 360 & 180 & 300 & 0 & 0 & 2 & 20 & 4.4 & 50 & 65 & 55 & 37 & 2 & 0 & 11 & 139 \\
\hline ISSM-N2 & 432 & 180 & 300 & 0 & 0 & 2 & 20 & 4.4 & 50 & 65 & 55 & 37 & 2 & 0 & 11 & 177 \\
\hline ISSM-N3 & 480 & 216 & 360 & 225 & 15 & 2 & 27 & 6 & 50 & 65 & 55 & 37 & 2 & 2250 & 11 & 177 \\
\hline \multirow[t]{2}{*}{ ISSM-N4 } & 600 & 252 & 450 & 225 & 15 & 2 & 41 & 9 & 50 & 65 & 55 & 37 & 2 & 2250 & 11 & 275 \\
\hline & \multicolumn{8}{|c|}{ Chemical input (Ei) $\left(\mathrm{kg} \mathrm{CO}_{2}\right.$ eq. $\left.\mathrm{ha}^{-1}\right)$} & \multicolumn{8}{|c|}{ Farm operation (Eo) $\left(\mathrm{kg} \mathrm{CO}_{2}\right.$ eq. ha $\left.{ }^{-1}\right)$} \\
\hline $\mathrm{NN}$ & 0 & 132 & 165 & 0 & 0 & 46 & 338 & 53 & 1419 & 1514 & 1514 & 127 & 23 & 0 & 37 & 36 \\
\hline FP & 2288 & 132 & 165 & 0 & 0 & 46 & 375 & 59 & 1419 & 1514 & 1514 & 127 & 23 & 0 & 37 & 39 \\
\hline ISSM-N1 & 1716 & 132 & 165 & 0 & 0 & 46 & 375 & 59 & 946 & 1230 & 1041 & 127 & 23 & 0 & 37 & 37 \\
\hline ISSM-N2 & 2059 & 132 & 165 & 0 & 0 & 46 & 375 & 59 & 946 & 1230 & 1041 & 127 & 23 & 0 & 37 & 47 \\
\hline ISSM-N3 & 2288 & 158 & 198 & 58 & 6 & 46 & 506 & 79 & 946 & 1230 & 1041 & 127 & 23 & 62 & 37 & 47 \\
\hline ISSM-N4 & 2860 & 185 & 248 & 58 & 6 & 46 & 768 & 129 & 946 & 1230 & 1041 & 127 & 23 & 62 & 37 & 73 \\
\hline
\end{tabular}

${ }^{\mathrm{a}}$ The carbon emission coefficients were 1.3,0.2,0.15, 6.3, 5.1 and $3.9 \mathrm{C}$ cost (kg Ceq. $\mathrm{g}^{-1}$ active ingredient) per applied nitrogen fertilizer, phosphorus, potassium, herbicide, insecticide and fungicide, respectively, as referred to in Lal (2004). We

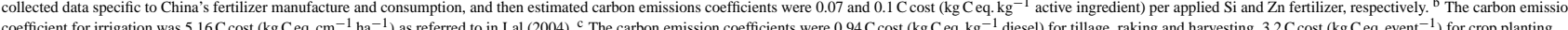

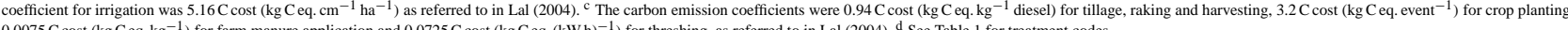
$0.0075 \mathrm{C}$ cost $\left(\mathrm{kg} \mathrm{Ceq} \mathrm{kg}^{-1}\right)$ for farm manure application and $0.0725 \mathrm{C}$ cost $\left(\mathrm{kg} \mathrm{Ceq}(\mathrm{kW} \mathrm{h})^{-1}\right)$ for threshing, as referred to in Lal (2004). ${ }^{\mathrm{d}}$ See Table 1 for treatment codes.

sain et al., 2008). As expected, when the total $\mathrm{N}$ rate was at the FP rate and/or increased by $25 \%$, in combination with other ISSM strategies (e.g., rapeseed cake manure, additional $\mathrm{P}$ and $\mathrm{K}$, applying $\mathrm{Si}$ and $\mathrm{Zn}$ fertilizer), the rice yield in these ISSM-N3 and ISSM-N4 plots increased substantially by 28 and $41 \%$, respectively. Based on a long-term fertilizer experiment, Shang et al. (2011) reported that organic fertilizer incorporation significantly increased the early rice grain yield. This may have resulted from the organic fertilizer applied in combination with adequate nutrients contributing to alleviating potential yield-limiting factors of rice.

It has been suggested that $\mathrm{N}$ losses vary depending on the timing, rate and method of $\mathrm{N}$ application, as well as the source of $\mathrm{N}$ fertilizer (Zhu, 1997). In addition to high rates of $\mathrm{N}$ and improper timing of $\mathrm{N}$ application, rapid $\mathrm{N}$ losses (via ammonia volatilization, denitrification, surface runoff and leaching) are important factors that cause low agronomic NUE of irrigated rice in China (Peng et al., 2006). Compared with the FP plot, the rice agronomic NUE was significantly increased by 75, 67, 35 and $40 \%$ under the ISSM-N1, ISSM-N2, ISSM-N3 and ISSM-N4 scenarios, respectively (Fig. 2). The higher rice agronomic NUE in our study over the experimental period could be due to reduced $\mathrm{N}$ losses by leaching and volatilization as well as the improvement of $\mathrm{N}$ bioavailability in the rice crop season (Zhao et al., 2015). Organic/inorganic combination fertilizer application also increases uptake by crops compared with the traditional farmers' practice (Peng et al., 2006). These findings suggest that the ISSM strategy is an effective method for improving grain yield and agronomic NUE for future sustainable rice agriculture in China.

\section{2 $\mathrm{CH}_{4}$ and $\mathrm{N}_{2} \mathrm{O}$ emissions as affected by ISSM strategies}

During the 3 years, the annual cumulative $\mathrm{CH}_{4}$ emissions, on average, varied from 133 to $469 \mathrm{~kg} \mathrm{Cha}^{-1} \mathrm{yr}^{-1}$ (Table 3 ), and these values fell within the range of 4.1 to $1015.6 \mathrm{~kg} \mathrm{CH}_{4} \mathrm{ha}^{-1}$ observed previously in a rice field (Huang et al., 2004). Methane emissions were highest during rice season, but only during the flooding period, mainly because $\mathrm{CH}_{4}$ was produced in the anaerobic zones of submerged soils by methanogens and is oxidized into $\mathrm{CO}_{2}$ by methanotrophs in the aerobic zones of wetland soils and in upland soils (Le Mer and Roger, 2001). The MANOVA results indicated that obvious effects of cultivation patterns and years on $\mathrm{CH}_{4}$ emissions were found during the ricewheat rotations (Table $4, P<0.001$ ). The $\mathrm{CH}_{4}$ emissions were not significantly affected by the cycles but affected by crop season (Table 6, Fig. 3). In this study, no significant difference in $\mathrm{CH}_{4}$ emission was observed between the FP, ISSM-N1 and ISSM-N2 plots. However, compared with the FP plot, the ISSM-N3 and ISSM-N4 scenarios emitted 87 and $118 \%$ more $\mathrm{CH}_{4}$, respectively (Table 6), which is probably due to the incorporation of the organic rapeseed cake manure. Previous reports support the observations that $\mathrm{CH}_{4}$ emissions were significantly increased with the application of organic amendments (Ma et al., 2009; Thangarajan et al., 2013; Zou et al., 2005). Apparently, additional application of $\mathrm{Si}$ and $\mathrm{Zn}$ fertilizers had no significant effect on $\mathrm{CH}_{4}$ and $\mathrm{N}_{2} \mathrm{O}$ fluxes, which was consistent with the result of Xie et al. (2015). Moreover, rice growth was found to be significantly increased under the ISSM-N3 and ISSM-N4 scenarios. In this case, the organic matter inputs such as root litter and rhizodeposits in the ISSM-N3 and ISSM-N4 scenarios were probably also higher than in the other plots; and thus 
Table 6. Mean global warming potential (GWP) and greenhouse gas intensity (GHGI) over the three rice season, wheat season and annual cycles of the 2011 rice season-2014 wheat season.

\begin{tabular}{|c|c|c|c|c|c|c|c|c|}
\hline \multirow[t]{2}{*}{ Treatment } & $\mathrm{CH}_{4}$ & $\mathrm{~N}_{2} \mathrm{O}$ & $\mathrm{Ei}$ & Eo & SOCSR & GWP $^{\mathrm{a}}$ & \multirow{2}{*}{$\begin{array}{l}\text { Grain yield } \\
\mathrm{tha}^{-1} \mathrm{yr}^{-1}\end{array}$} & \multirow{2}{*}{$\begin{array}{r}\mathrm{GHGI}^{\mathrm{b}} \\
\mathrm{kg} \mathrm{CO}_{2} \text { eq. } \mathrm{t}^{-1} \text { grain }\end{array}$} \\
\hline & \multicolumn{6}{|c|}{$\mathrm{kg} \mathrm{CO}_{2}$ eq. ha ${ }^{-1} \mathrm{yr}^{-1}$} & & \\
\hline \multicolumn{9}{|c|}{ Rice season } \\
\hline $\mathrm{NN}$ & $5026 \pm 733 d$ & $44 \pm 20 c$ & 424 & 1601 & $-396 \pm 164 c$ & $7492 \pm 706 d$ & $5.83 \pm 0.04 \mathrm{f}$ & $1285 \pm 123 b$ \\
\hline FP & $8035 \pm 742 c$ & $121 \pm 53 b c$ & 1859 & 1603 & $585 \pm 198 \mathrm{ab}$ & $11032 \pm 555 c$ & $8.59 \pm 0.25 \mathrm{e}$ & $1285 \pm 68 b$ \\
\hline ISSM-N1 & $7132 \pm 716 c$ & $75 \pm 24 c$ & 1502 & 1191 & $246 \pm 218 b$ & $9654 \pm 800 \mathrm{c}$ & $9.45 \pm 0.18 \mathrm{~d}$ & $1021 \pm 81 \mathrm{c}$ \\
\hline ISSM-N2 & $7186 \pm 434 c$ & $112 \pm 49 b c$ & 1716 & 1198 & $355 \pm 97 \mathrm{ab}$ & $9858 \pm 484 c$ & $9.98 \pm 0.25 c$ & $989 \pm 67 c$ \\
\hline ISSM-N3 & $15005 \pm 888 b$ & $208 \pm 66 a b$ & 2037 & 1260 & $691 \pm 252 \mathrm{a}$ & $17818 \pm 786 b$ & $10.95 \pm 0.13 b$ & $1626 \pm 54 a$ \\
\hline ISSM-N4 & $17427 \pm 1463 a$ & $284 \pm 60 \mathrm{a}$ & 2626 & 1280 & $773 \pm 174 a$ & $20844 \pm 1452 \mathrm{a}$ & $12.11 \pm 0.28 \mathrm{a}$ & $1720 \pm 108 \mathrm{a}$ \\
\hline \multicolumn{9}{|c|}{ Wheat season } \\
\hline $\mathrm{NN}$ & $-78 \pm 71 \mathrm{a}$ & $201 \pm 28 d$ & 310 & 104 & $-396 \pm 164 c$ & $934 \pm 214 b$ & $1.75 \pm 0.04 \mathrm{~d}$ & $533 \pm 125 a$ \\
\hline FP & $8 \pm 148 \mathrm{a}$ & $605 \pm 99 b$ & 1206 & 105 & $585 \pm 198 \mathrm{ab}$ & $1339 \pm 129 b$ & $5.67 \pm 0.16 b$ & $236 \pm 21 b$ \\
\hline ISSM-N1 & $16 \pm 103 a$ & $351 \pm 32 c$ & 991 & 105 & $246 \pm 218 b$ & $1217 \pm 342 b$ & $5.04 \pm 0.08 \mathrm{c}$ & $241 \pm 68 b$ \\
\hline ISSM-N2 & $6 \pm 22 a$ & $451 \pm 49 \mathrm{c}$ & 1120 & 108 & $355 \pm 97 \mathrm{ab}$ & $1329 \pm 109 b$ & $5.76 \pm 0.22 \mathrm{ab}$ & $231 \pm 26 b$ \\
\hline ISSM-N3 & $23 \pm 131 \mathrm{a}$ & $598 \pm 20 b$ & 1302 & 108 & $691 \pm 252 \mathrm{a}$ & $1340 \pm 290 b$ & $5.40 \pm 0.16 b c$ & $247 \pm 48 b$ \\
\hline ISSM-N4 & $79 \pm 96 a$ & $772 \pm 66 \mathrm{a}$ & 1674 & 114 & $773 \pm 174 a$ & $1867 \pm 175 \mathrm{a}$ & $6.14 \pm 0.35 \mathrm{a}$ & $305 \pm 33 b$ \\
\hline \multicolumn{9}{|c|}{ Rice-wheat rotation } \\
\hline $\mathrm{NN}^{\mathrm{d}}$ & $4948 \pm 704 \mathrm{~d}^{\mathrm{c}}$ & $246 \pm 26 d$ & 734 & 1705 & $-792 \pm 327 c$ & $8425 \pm 711 d$ & $7.58 \pm 0.04 d$ & $1111 \pm 94 \mathrm{~b}$ \\
\hline FP & $8043 \pm 858 c$ & $725 \pm 49 b$ & 3065 & 1708 & $1170 \pm 396 a b$ & $12371 \pm 583 c$ & $14.26 \pm 0.36 c$ & $868 \pm 29 c$ \\
\hline ISSM-N1 & $7141 \pm 709 c$ & $426 \pm 55 c$ & 2493 & 1296 & $491 \pm 435 b$ & $10871 \pm 990 \mathrm{c}$ & $14.50 \pm 0.14 c$ & $750 \pm 68 d$ \\
\hline ISSM-N2 & $7192 \pm 424 c$ & $563 \pm 86 c$ & 2836 & 1306 & $709 \pm 193 a b$ & $11187 \pm 552 \mathrm{c}$ & $15.74 \pm 0.44 b$ & $712 \pm 52 d$ \\
\hline ISSM-N3 & $15028 \pm 833 b$ & $806 \pm 77 b$ & 3339 & 1368 & $1383 \pm 503 a$ & $19158 \pm 761 b$ & $16.36 \pm 0.18 b$ & $1171 \pm 37 \mathrm{ab}$ \\
\hline ISSM-N4 & $17506 \pm 1396 a$ & $1056 \pm 58 \mathrm{a}$ & 4300 & 1394 & $1545 \pm 348 \mathrm{a}$ & $22711 \pm 1438 a$ & $18.26 \pm 0.46 \mathrm{a}$ & $1245 \pm 93 a$ \\
\hline
\end{tabular}

${ }^{\mathrm{a}} \mathrm{GWP}\left(\mathrm{kg} \mathrm{CO}_{2}\right.$ eq. ha $\left.^{-1} \mathrm{yr}^{-1}\right)=28 \times \mathrm{CH}_{4}+265 \times \mathrm{N}_{2} \mathrm{O}+\mathrm{Ei}+\mathrm{Eo}-44 / 12 \times \mathrm{SOCSR}$, Ei (agrochemical input), Eo (farm operation), SOCSR (SOC sequestration rate) is divided by 2 to roughly estimate the GWP from rice and wheat season, respectively. All other items were actually measured for each season. ${ }^{\mathrm{b}} \mathrm{GHGI}\left(\mathrm{kg} \mathrm{CO} \mathrm{CO}_{2}\right.$ eq. $\mathrm{t}^{-1}$ grain) $=\mathrm{GWP} / \mathrm{grain}$ yields ${ }^{\mathrm{c}} \mathrm{Different}$ lower case letters within the same column for each item indicate significant differences at $P<0.05$ based on Tukey's multiple range tests. ${ }^{\mathrm{d}}$ See Table 1 for treatment codes.

soil $\mathrm{C}$ input, which served as an additional source of substrates for the methanogens in the rice paddies, likely contributed to the increase in $\mathrm{CH}_{4}$ emissions (Ma et al., 2009). Finally, because the rice plants acted as the main pathway for $\mathrm{CH}_{4}$ transports from the soil to the atmosphere, the higher biomass may have facilitated more $\mathrm{CH}_{4}$ emissions (Yan et al., 2005).

Denitrification and nitrification are the main processes that produce $\mathrm{N}_{2} \mathrm{O}$ in the soil (Paul et al., 1993). The $\mathrm{N}_{2} \mathrm{O}$ emission patterns varied during the rice- and wheat-growing seasons which were partially associated with the anaerobic conditions prevailing in a rice paddy. Changes in the soil water content strongly influenced the soil $\mathrm{N}_{2} \mathrm{O}$ emissions and resulted in negligible $\mathrm{N}_{2} \mathrm{O}$ emissions when the rice field was flooded (Fig. 4), which is consistent with previous reports (Akiyama et al., 2005; Murdiyarso et al., 2010). When the soil water content was below saturation, $\mathrm{N}_{2} \mathrm{O}$ emissions increase with soil moisture; however, $\mathrm{N}_{2} \mathrm{O}$ emissions gradually decreased with the soil saturation condition (Rudaz et al., 1999). A relatively high $\mathrm{N}_{2} \mathrm{O}$ peak was observed in the first 2 weeks of the wheat-growing season (Fig. 4), possibly because soil changes from flooded to drained conditions may have enhanced $\mathrm{N}_{2} \mathrm{O}$ release (Deng et al., 2012). Alternation of drainage and flooding may induce large amounts of $\mathrm{N}_{2} \mathrm{O}$ emissions, particularly in fertilized systems; this has commonly been shown in earlier studies (Wang et al., 2012; Xiong et al., 2007; Zou et al., 2005). The seasonal and annual rates of $\mathrm{N}_{2} \mathrm{O}$ emissions were significantly affected by the cultivation practices and years (Table 4). Compared with the FP plot, the ISSM-N2 scenario significantly decreased the seasonal $\mathrm{N}_{2} \mathrm{O}$ emissions in this study, which may have resulted from a reduction in the $\mathrm{N}$ fertilizer rate (Tables 1,3). The total $\mathrm{N}_{2} \mathrm{O}$ emissions decreased by $7-38$ and $26-42 \%$ in the rice and wheat seasons, respectively, when the conventional $\mathrm{N}$ management $\left(300 \mathrm{~kg} \mathrm{Nha}^{-1}\right.$ for rice and $180 \mathrm{~kg} \mathrm{Nha}^{-1}$ per crop for wheat) changed to optimum $\mathrm{N}$ management (225$270 \mathrm{~kg} \mathrm{Nha}^{-1}$ for rice and $135-162 \mathrm{~kg} \mathrm{Nha}^{-1}$ per crop for wheat). It is likely that more $\mathrm{N}_{2} \mathrm{O}$ was emitted (Mosier et al., 2006) as a result of the additional $\mathrm{N}$ made available to the soil microbes through $\mathrm{N}$ fertilizer application, which also probably contributed to increased $\mathrm{CH}_{4}$ emissions (Banger et al., 2013). Strategies that can reduce $\mathrm{N}$ fertilization rates without influencing crop yields can inevitably lower GHG emissions (Mosier et al., 2006). Nitrogen leaching and volatilization are the important components of reactive $\mathrm{N}$ releases but are not included in the current GHG budget. 


\subsection{GWP and GHGI as affected by ISSM strategies}

The GWP in our study (10871-22711 $\mathrm{kg} \mathrm{CO}_{2}$ eq. ha ${ }^{-1}$ ) with the ISSM strategies was higher than that in a doublecropping cereal rotation (1346-4684 $\mathrm{kg} \mathrm{CO}_{2}$ eq. ha ${ }^{-1}$ ) and a rice-wheat annual rotation $\left(290-4580 \mathrm{~kg} \mathrm{CO}_{2}\right.$ eq. ha $\left.{ }^{-1}\right)$ reported by Huang et al. (2013b) and Yang et al. (2015), respectively. Dominant $\mathrm{CH}_{4}$ emissions as well as additional $\mathrm{CO}_{2}$ emissions due to the use of machinery/equipment for irrigation and farm operations under the ISSM strategies may increase the GWP more than in other cropping systems (emit more $\mathrm{CO}_{2}$ equivalent emissions of 2439$5694 \mathrm{~kg} \mathrm{CO}_{2}$ eq. ha ${ }^{-1}$ for agricultural management practices in the present study). However, the current GWP was comparable to that of a double-rice cropping system (13407$26066 \mathrm{~kg} \mathrm{CO}_{2}$ eq. ha ${ }^{-1}$ ) (Shang et al., 2011). The GHGIs, which ranged from 0.71 to $1.25 \mathrm{~kg} \mathrm{CO}_{2}$ eq. $\mathrm{kg}^{-1}$ grain in this study, were slightly higher than previous estimates of $0.24-0.74 \mathrm{~kg} \mathrm{CO}_{2}$ eq. $\mathrm{kg}^{-1}$ grain from rice paddies with midseason drainage and organic manure incorporation (Qin et al., 2010; Li et al., 2006), but were lower than the DNDC model estimates for continuous waterlogged paddies ( $3.22 \mathrm{~kg} \mathrm{CO}_{2}$ eq. $\mathrm{kg}^{-1}$ grain) (Li et al., 2006). Differences in GWP or GHGI were found in the cultivation patterns over the three rice-wheat rotations (Table 6). The ISSMN1 and ISSM-N2 scenarios with optimized ISSM strategies led to a lower GWP than the FP by a certain extent, but there were not significant differences among the FP, ISSM-N1 and ISSM-N2 plots (Table 6). Compared with the FP, the ISSM-N1 and ISSM-N2 scenarios significantly reduced the GHGI, which was mainly due to higher yields. In spite of the similar GWP compared with the FP plot, the lowest GHGI $\left(0.71 \mathrm{~kg} \mathrm{CO}_{2}\right.$ eq. $\mathrm{kg}^{-1}$ grain) was obtained under the ISSM-N2 scenario. This finding is consistent with the suggestion made by Burney et al. (2010), i.e., that the net effect of higher yields offsets emissions. It is well known that $\mathrm{CH}_{4}$ emissions dominate the GWP in rice paddies (Ma et al., 2013; Shang et al., 2011). In comparison to the GWP $\left(12371 \mathrm{kgCO}_{2}\right.$ eq. $\left.\mathrm{ha}^{-1} \mathrm{yr}^{-1}\right)$ and GHGI ( $0.87 \mathrm{~kg} \mathrm{CO}_{2}$ eq. $\mathrm{kg}^{-1}$ grain) of the FP, the ISSM-N3 and ISSM-N4 scenarios increased both the GWP and GHGI, mainly because these scenarios notably increased the $\mathrm{CH}_{4}$ emissions compared with the FP, which resulted in relatively higher GWP (Table 6).

Agricultural management practices that change one type of GWP source/sink may also impact other sources/sinks and therefore change the GWP and GHGI (Mosier et al., 2006; Shang et al., 2011). Although the $\mathrm{N}$ fertilizer plots, especially those with the incorporation of organic fertilizer, increased the annual $\mathrm{CH}_{4}$ and $\mathrm{N}_{2} \mathrm{O}$ emissions, they increased the SOC sequestration in this cropping system, which is in agreement with previous reports (Huang and Sun, 2006). This may be due to the incorporation of rapeseed cake and enhanced below-ground crop residue associated with higher crop productivity (Ma et al., 2013). In the present study, the
ISSM-N2 scenario with ISSM strategies decreased the $\mathrm{CH}_{4}$ and $\mathrm{N}_{2} \mathrm{O}$ emissions as well as the energy consumption related to irrigation and the manufacture and transport of $\mathrm{N}$ fertilizer (depending on coal combustion), ultimately leading to a decrease in the GWP relative to the FP plot. Moreover, despite the lower $\mathrm{N}$ fertilizer input, the grain yield did not decline and the GHGI of the ISSM-N2 scenario was thus lower than of the FP plot, indicating less consumption of $\mathrm{CO}_{2}$ equivalents per unit of grain produced. We demonstrate that high yield and agronomic NUE, together with low GWP, are not conflicting goals by optimizing ISSM strategies.

\subsection{Main components of GWP and GHGI and implementation significance for the ISSM strategies}

Determining the main components of the GWP and GHGI in specific cropping systems is very important for mitigating GHG emissions in the future, because the benefits of $\mathrm{C}$ sequestration would be negated by $\mathrm{CH}_{4}$ and $\mathrm{N}_{2} \mathrm{O}$ emissions and the $\mathrm{CO}_{2}$ equivalents released with the use of high $\mathrm{N}$ fertilizer application rates (Schlesinger, 2010). In the current study, the five main components of the $\mathrm{CO}_{2}$ equivalents for the GWP were ranked in decreasing order of importance as follows: $\mathrm{CH}_{4}$ emissions > agrochemical inputs of $\mathrm{N}$ fertilizer $>$ farm operations related to irrigation $>$ SOC sequestration $>\mathrm{N}_{2} \mathrm{O}$ emissions (Table 6). Of the two crops, $\mathrm{CH}_{4}$ and irrigation were important for rice, but less important for wheat, in which $\mathrm{N}_{2} \mathrm{O}$ losses were expected to have a higher weight (Table 2). Methane emissions, the most important component of GWP in this typical rice-wheat rotation system, could be further mitigated by some other strategies, such as reasonable irrigation (Zou et al., 2005; Wang et al., 2012).

Although $\mathrm{N}$ fertilizer application increased SOC sequestration when it was applied with rapeseed cake manure, this benefit was consistently overshadowed, on a $\mathrm{CO}_{2}$ equivalent basis, by the increases in $\mathrm{CH}_{4}$ and $\mathrm{N}_{2} \mathrm{O}$ emissions (Table 6). Similar results have been reported, i.e., GHG emissions substantially offset SOC increases (Six et al., 2004). It is possible that the realization of reducing the GWP and GHGI in China should focus on increasing the SOC and simultaneously decreasing the $\mathrm{CO}_{2}$ equivalents from $\mathrm{CH}_{4}$ emissions and $\mathrm{N}$ fertilizer inputs. Several studies reported possible methods for these types of mitigation strategies, such as optimizing the chemical fertilizer application amount and rate (Ju et al., 2011), the amount of water used for irrigation (Gao et al., 2015) and the timing and rate of $\mathrm{N}$ using the in-season $\mathrm{N}$ management approach, as well as improving the $\mathrm{N}$ fertilizer manufacturing technologies (Zhang et al., 2013) and using nitrification inhibitors or polymer-coated controlled-release fertilizers (Hu et al., 2013).

China is a rapidly developing country that faces the dual challenge of substantially increasing grain yields and at the same time reducing the substantial environmental impact of intensive agriculture (Chen et al., 2011). We used the ISSM strategies to develop a rice production system that achieved 
mean yields of $10.63 \mathrm{tha}^{-1}$ (an increment of almost $24 \%$ )

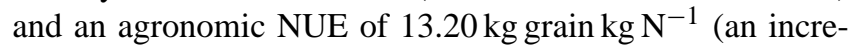
ment of $43 \%$ ) in long-term field experiments compared with current farmers' practices. The ISSM redesigned the whole production system only for the rice crop based on the local environment, drawing on appropriate fertilizer varieties and application ratios, crop densities and an advanced water regime management. If the ISSM strategies were also developed for the rotated wheat crop, the overall performance of the whole rice-wheat system would be much improved, with further increases in yield and reductions in the GWP and GHGI. We conclude that the ISSM strategies are promising, particularly the ISSM-N2 scenario, which is the most favorable to realize higher yields with lower environmental impact. The proposed ISSM strategies can provide substantial benefits to intensive agricultural systems, and can be applied feasibly using current technologies.

\section{Conclusions}

Reasonable agricultural management practices are the key to reducing GHG emissions from agricultural ecosystems. This study provided an insight into the complete GHG emission accounting of the GWP and GHGI affected by different ISSM scenarios. After a 3-year field experiment, we found that the $\mathrm{CH}_{4}$ emissions, production of $\mathrm{N}$ fertilizer, irrigation, SOC sequestration and $\mathrm{N}_{2} \mathrm{O}$ fluxes were the main components of the GWP in a typical rice-wheat rotation system. In contrast with the FP, ISSM-N1 and ISSM-N2 significantly reduced the GHGI, though they resulted in similar GWPs, and ISSM-N3 and ISSM-N4 remarkably increased the GWP and GHGI. By adopting the ISSM-N2 strategy, the conventional $\mathrm{N}$ application rate was reduced by $10 \%$, while the rice yield was significantly increased by $16 \%$, the NUE was improved by $67 \%$ and the GHGI was lowered by $23 \%$. ISSM scenarios could be adopted for both food security and environmental protection with specific targets. We propose that the ISSM-N2 scenario is the most appropriate management strategy ( $10 \%$ reduction of $\mathrm{N}$ input, no rapeseed manure and higher plant density) for realizing higher yields and NUE, together with some potential to reduce GHGI by integrated soil-crop management. For simultaneously mitigating GHG emissions, further research on integrated soil-crop system management is required, particularly for mitigating $\mathrm{CH}_{4}$ emissions in sustainable rice agriculture.

Acknowledgements. We sincerely appreciate two anonymous reviewers for their critical and valuable comments to help improve this manuscript. This work was jointly supported by the National Science Foundation of China (41171238, 41471192), the Special Fund for Agro-Scientific Research in the Public Interest (201503106) and the Ministry of Science and Technology (2013BAD11B01).
Edited by: T. Treude

\section{References}

Akiyama, H., Yagi, K., and Yan, X. Y.: Direct $\mathrm{N}_{2} \mathrm{O}$ emissions from rice paddy fields: summary of available data, Global Biogeochem. Cy., 19, GB002378, doi:10.1029/2004GB002378, 2005.

Banger, K., Tian, H., and Lu, C.: Do nitrogen fertilizers stimulate or inhibit methane emissions from rice fields?, Glob. Change Biol., 18, 3259-3267, 2013.

Barrett, C. B.: Measuring food insecurity, Science, 327, 825-828, 2010.

Burney, J. A., Davis, S. J., and Lobell, D. B.: Greenhouse gas mitigation by agricultural intensification, P. Natl. Acad. Sci. USA, 107, 12052-12057, 2010.

Chen, X., Cui, Z., Vitousek, P. M., Cassman, K. G., Matson, P. A., Bai, J., Meng, Q., Hou, P., Yue, S., and Römheld, V.: Integrated soil-crop system management for food security, P. Natl. Acad. Sci. USA, 108, 6399-6404, 2011.

Chen, X., Cui, Z., Fan, M., Vitousek, P., Zhao, M., Ma, W., Wang, Z., Zhang, W., Yan, X., and Yang, J.: Producing more grain with lower environmental costs, Nature, 514, 486-489, 2014.

Deng, J., Zhou, Z., Zheng, X., Liu, C., Yao, Z., Xie, B., Cui, F., Han, S., and Zhu, J.: Annual emissions of nitrous oxide and nitric oxide from rice-wheat rotation and vegetable fields: a case study in the Tai-Lake region, China, Plant Soil, 360, 37-53, doi:10.1007/s11104-012-1223-6, 2012.

Food and Agriculture Organization Statistical Data (FAOSTAT): Rice production in the Asia-pacific region: issues and prespectives, available at: http://www.fao.org/docrep/003/x6905e/ x6905e04.htm (last access: date: 28 December 2015), Rome, Italy, 2010.

Frolking, S., Qiu, J., Boles, S., Xiao, X., Liu, J., Zhuang, Y., Li, C., and Qin, X.: Combining remote sensing and ground census data to develop new maps of the distribution of rice agriculture in China, Global Biogeochem. Cy., 16, GB001425, doi:10.1029/2001GB001425, 2002.

Gao, B., Ju, X., Meng, Q., Cui, Z., Christie, P., Chen, X., and Zhang, F.: The impact of alternative cropping systems on global warming potential, grain yield and groundwater use, Agr. Ecosyst. Environ., 203, 46-54, 2015.

Hossain, M. A., Jahiruddin, M., Islam, M. R., and Mian, M. H.: The requirement of zinc for improvement of crop yield and mineral nutrition in the maize-mungbean-rice system, Plant Soil, 306, 13-22, 2008.

Hu, X., Su, F., Ju, X., Gao, B., Oenema, O., Christie, P., Huang, B., Jiang, R., and Zhang, F.: Greenhouse gas emissions from a wheat-maize double cropping system with different nitrogen fertilization regimes, Environ. Pollut., 176, 198-207, 2013.

Huang, J., Chen, Y., Sui, P., and Gao, W.: Estimation of net greenhouse gas balance using crop-and soil-based approaches: Two case studies, Sci. Total Environ., 456, 299-306, 2013a.

Huang, T., Gao, B., Christie, P., and Ju, X.: Net global warming potential and greenhouse gas intensity in a double-cropping cereal rotation as affected by nitrogen and straw management, Biogeosciences, 10, 7897-7911, doi:10.5194/bg-10-7897-2013, 2013 b. 
Huang, Y. and Sun, W.: Changes in topsoil organic carbon of croplands in mainland China over the last two decades, Chinese Sci. Bull., 51, 1785-1803, 2006.

Huang, Y., Zhang, W., Zheng, X. H., Li, J., and Yu, Y. Q.: Modeling methane emission from rice paddies with various agricultural practices, J. Geophys. Res.-Atmos., 109, D08113, doi:10.1029/2003JD004401, 2004.

IPCC: Climate Change 2013: The Physical Science Basis: working group I contribution to the Fifth Assessment Report of the Intergovernmental Panel on Climate Change, Cambridge University Press, Stockholm, 2013.

Jia, J. X., Ma, Y. C., and Xiong, Z. Q.: Net ecosystem carbon budget, net global warming potential and greenhouse gas intensity in intensive vegetable ecosystems in China, Agr. Ecosyst. Environ., 150, 27-37, 2012.

Ju, X., Xing, G., Chen, X., Zhang, S., Zhang, L., Liu, X., Cui, Z., Yin, B., Christie, P., and Zhu, Z.: Reducing environmental risk by improving $\mathrm{N}$ management in intensive Chinese agricultural systems, P. Natl. Acad. Sci. USA, 106, 3041-3046, 2009.

Ju, X., Lu, X., Gao, Z., Chen, X., Su, F., Kogge, M., Römheld, V., Christie, P., and Zhang, F.: Processes and factors controlling $\mathrm{N}_{2} \mathrm{O}$ production in an intensively managed low carbon calcareous soil under sub-humid monsoon conditions, Environ. Pollut., 159, 1007-1016, 2011.

Kabata-Pendias, A. and Mukherjee, A. B.: Trace Elements from Soil to Human, Springer, Berlin, 2007.

Lal, R.: Carbon emission from farm operations, Environ. Int., 30, 981-990, 2004.

Le Mer, J. and Roger, P.: Production, oxidation, emission and consumption of methane by soils: a review, Eur. J. Soil Biol., 37, 25-50, 2001.

Li, C. S., Salas, W., DeAngelo, B., and Rose, S.: Assessing alternatives for mitigating net greenhouse gas emissions and increasing yields from rice production in China over the next twenty years, J. Environ. Qual., 35, 1554-1565, 2006.

Liu, L., Xue Y., Sun, X., Wang, Z., and Yang, J.: Effects of water management methods on grain yield and fertilizer-nitrogen use efficiency in rice, Chin. J. Rice Sci., 23, 282-288, 2009.

Liu, Y. L., Zhou, Z., Zhang, X., Xu, X., Chen, H., and Xiong, Z.: Net global warming potential and greenhouse gas intensity from the double rice system with integrated soil-crop system management: A three-year field study, Atmos. Environ., 116, 92-101, 2015.

Ma, J., Ma, E., Xu, H., Yagi, K., and Cai, Z.: Wheat straw management affects $\mathrm{CH}_{4}$ and $\mathrm{N}_{2} \mathrm{O}$ emissions from rice fields, Soil Biol. Biochem., 41, 1022-1028, 2009.

Ma, Y., Kong, X., Yang, B., Zhang, X., Yan, X., Yang, J., and Xiong, Z.: Net global warming potential and greenhouse gas intensity of annual rice-wheat rotations with integrated soil-crop system management, Agr. Ecosyst. Environ., 164, 209-219, 2013.

Makino, A.: Photosynthesis, grain yield, and nitrogen utilization in rice and wheat, Plant Physiol., 155, 125-129, 2011.

Mosier, A. R., Halvorson, A. D., Reule, C. A., and Liu, X. J.: Net global warming potential and greenhouse gas intensity in irrigated cropping systems in northeastern Colorado, J. Environ. Qual., 35, 1584-1598, 2006.

Murdiyarso, D., Hergoualc'h, K., and Verchot, L. V.: Opportunities for reducing greenhouse gas emissions in tropical peatlands, $\mathrm{P}$. Natl. Acad. Sci. USA, 107, 19655-19660, 2010.
Myhre, G., Shindell, D., Bréon, F. M., Collins, W., Fuglestvedt, J., Huang, J., Koch, D., Lamarque, J. F., Lee, D., Mendoza, B., Nakajima, T., Robock, A., Stephens, G., Takemura, T., and Zhang, H.: Anthropogenic and natural radiative forcing, in: Stocker, T. F., Qin, D., Plattner, G. K., Tignor, M., Allen, S. K., Boschung, J., Nauels, A., Xia, Y., Bex, V., and Midgley, P. M., Climate Change 2013: The Physical Science Basis, Contribution of Working Group I to the Fifth Assessment Report of the Intergovernmental Panel on Climate Change, Cambridge University Press, Cambridge, UK, New York, NY, USA, 659-740, 2013.

Paul, J. W., Beauchamp, E. G., and Zhang, X.: Nitrous and nitric oxide emissions during nitrification and denitrification from manure-amended soil in the laboratory, Can. J. Soil. Sci., 73, 539-553, 1993.

Peng, S., Buresh, R. J., Huang, J., Yang, J., Zou, Y., Zhong, X., Wang, G., and Zhang, F.: Strategies for overcoming low agronomic nitrogen use efficiency in irrigated rice systems in China, Field Crop. Res., 96, 37-47, 2006.

Qin, Y. M., Liu, S.W., Guo, Y. Q., Liu, Q., and Zou, J. W.: Methane and nitrous oxide emissions from organic and conventional rice cropping systems in Southeast China, Biol. Fert. Soils., 46, 825834, 2010.

Robertson, G. P. and Grace, P. R.: Greenhouse gas fluxes in tropical and temperate agriculture: The need for a full-cost accounting of global warming potentials, Environment Development and Sustainability, 6, 51-63, 2004.

Rudaz, A. O., Wälti, E., Kyburz, G., Lehmann, P., and Fuhrer, J.: Temporal variation in $\mathrm{N}_{2} \mathrm{O}$ and $\mathrm{N}_{2}$ fluxes from a permanent pasture in Switzerland in relation to management, soil water content and soil temperature, Agr. Ecosyst. Environ., 73, 83-91, 1999.

Sainju, U. M., Stevens, W. B., Caesar-TonThat, T., Liebig, M. A., and Wang, J.: Net global warming potential and greenhouse gas intensity influenced by irrigation, tillage, crop rotation, and nitrogen fertilization, J. Environ. Qual., 43, 777-788, 2014.

Schlesinger, W. H.: On fertilizer-induced soil carbon sequestration in China's croplands, Glob. Change Biol., 16, 849-850, 2010.

Shang, Q., Yang, X., Gao, C., Wu, P., Liu, J., Xu, Y., Shen, Q., Zou, J., and Guo, S.: Net annual global warming potential and greenhouse gas intensity in Chinese double rice-cropping systems: a 3year field measurement in long-term fertilizer experiments, Glob. Change Biol., 17, 2196-2210, 2011.

Six, J., Ogle, S. M., Conant, R. T., Mosier, A. R., and Paustian, K.: The potential to mitigate global warming with no-tillage management is only realized when practised in the long term, Glob. Change Biol., 10, 155-160, 2004.

Slaton, N. A., Norman, R. J., and Wilson, C. E.: Effect of zinc source and application time on zinc uptake and grain yield of flood-irrigated rice, Agron. J., 97, 272-278, 2005.

Smith, P., Martino, D., Cai, Z., Gwary, D., Janzen, H., Kumar, P., McCarl, B., Ogle, S., O’Mara, F., and Rice, C.: Greenhouse gas mitigation in agriculture, Philos. T. R. Soc. B., 363, 789-813, 2008.

Snyder, C., Bruulsema, T., Jensen, T., and Fixen, P.: Review of greenhouse gas emissions from crop production systems and fertilizer management effects, Agr. Ecosyst. Environ., 133, 247266, 2009.

Thangarajan, R., Bolan, N. S., Tian, G., Naidu, R., and Kunhikrishnan, A.: Role of organic amendment application on greenhouse gas emission from soil, Sci. Total Environ., 465, 72-96, 2013. 
Tilman, D., Balzer, C., Hill, J., Befort, B. L., and Affiliations, A.: Global food demand and the sustainable intensification of agriculture, P. Natl. Acad. Sci. USA, 108, 20260-20264, 2011.

Wang, J., Zhang, X., Xiong, Z., Khalil, M. A. K., Zhao, X., Xie, Y., and Xing, G.: Methane emissions from a rice agroecosystem in South China: Effects of water regime, straw incorporation and nitrogen fertilizer, Nutr. Cycl. Agroecosy., 93, 103-112, 2012.

Wang, L. J., Nie, Q., Li, M., Zhang, F. S., Zhuang, J. Q., Yang, W. S., Li, T. J., and Wang, Y. H.: Biosilicified structures for cooling plant leaves: a mechanism of highly efficient midinfrared thermal emission, Appl. Phys. Lett., 87, 194105, doi:10.1063/1.2126115, 2005.

West, T. O. and Marland, G.: A synthesis of carbon sequestration, carbon emissions, and net carbon flux in agriculture: comparing tillage practices in the United States, Agr. Ecosyst. Environ., 91, 217-232, 2002.

Wu, C., Ye, D., Lin, H., Ni, R., Lai, L., and Lin, H.: Effects of transplanting density on rice yield and its quality, Chinese Agricultural Science Bulletin, 21, 190-205, 2005.

Xie, Y., Zhang, J., Jiang, H., Yang, J., Deng, S., Li, X., Guo, J., Li, L., Liu, X., and Zhou, G.: Effects of different fertilization practices on greenhouse gas emissions from paddy soil, Journal of Agro-Environment Science, 3, 578-584, 2015.

Xiong, Z. Q., Xing, G. X., and Zhu, Z. L.: Nitrous oxide and methane emissions as affected by water, soil and nitrogen, Pedosphere, 17, 146-155, 2007.

Yan, X. Y., Yagi, K., Akiyama, H., and Akimoto, H.: Statistical analysis of the major variables controlling methane emission from rice fields, Glob. Change Biol., 11, 1131-1141, 2005.
Yang, B., Xiong, Z., Wang, J., Xu, X., Huang, Q., and Shen, Q.: Mitigating net global warming potential and greenhouse gas intensities by substituting chemical nitrogen fertilizers with organic fertilization strategies in rice-wheat annual rotation systems in China: A 3-year field experiment, Ecol. Eng., 81, 289-297, 2015.

Zhang, F., Cui, Z., Fan, M., Zhang, W., Chen, X., and Jiang, R.: Integrated soil-crop system management: reducing environmental risk while increasing crop productivity and improving nutrient use efficiency in China, J. Environ Qual., 40, 1051-1057, 2011.

Zhang, W., Dou, Z., He, P., Ju, X., Powlson, D., Chadwick, D., Norse, D., Lu, Y., Zhang, Y., and Wu, L.: New technologies reduce greenhouse gas emissions from nitrogenous fertilizer in China, P. Natl. Acad. Sci. USA, 110, 8375-8380, 2013.

Zhang, X., Fan, C., Ma, Y., Liu, Y., Li, L., Zhou, Q., and Xiong, Z.: Two approaches for net ecosystem carbon budgets and soil carbon sequestration in a rice-wheat rotation system in China, Nutr. Cycl. Agroecosys., 100, 301-313, 2014.

Zhao, M., Tian, Y., Ma, Y., Zhang, M., Yao, Y., Xiong, Z., Yin, B., and Zhu, Z.: Mitigating gaseous nitrogen emissions intensity from a Chinese rice cropping system through an improved management practice aimed to close the yield gap, Agr. Ecosyst. Environ., 203, 36-45, 2015.

Zhu, Z.: Fate and management of fertilizer nitrogen in agroecosystems. Nitrogen in Soils of China, Springer, the Netherlands, 239-279, 1997.

Zou, J. W., Huang, Y., Jiang, J. Y., Zheng, X. H., and Sass, R. L.: A 3-year field measurement of methane and nitrous oxide emissions from rice paddies in China: effects of water regime, crop residue, and fertilizer application, Global Biogeochem. Cy., 19, GB002401, doi:10.1029/2004GB002401, 2005. 